Canadian Science Publishing

Canadian Journal of Earth Sciences Revue canadienne des sciences de la Terre

\title{
Geological setting of vertebrate microfossil localities across the Cretaceous-Paleogene boundary in southwestern Saskatchewan, Canada
}

\begin{tabular}{|r|l|}
\hline Journal: & Canadian Journal of Earth Sciences \\
\hline Manuscript ID: & cjes-2015-0038.R1 \\
\hline Manuscript Type: & Article \\
\hline Date Submitted by the Author: & 20 -Apr-2015 \\
\hline Complete List of Authors: & $\begin{array}{l}\text { Redman, Cory; Royal Tyrrell Museum of Palaeontology, } \\
\text { Gardner, James D.; Royal Tyrell Museum of Palaeontology, } \\
\text { Scott, Craig; Royal Tyrell Museum of Palaeontology, } \\
\text { Braman, Dennis; Royal Tyrrell Museum of Palaeontology }\end{array}$ \\
\hline Keyword: & Maastrichtian, Paleocene, microvertebrates, mammals, terrestrial \\
\hline \multicolumn{2}{|l}{} \\
\hline
\end{tabular}

\section{SCHOLARONE ${ }^{\text {M }}$ \\ Manuscripts}




\section{Geological setting of vertebrate microfossil localities across the Cretaceous-Paleogene boundary in southwestern Saskatchewan, Canada}

Cory M. Redman, James D. Gardner, Craig S. Scott, and Dennis R. Braman

Cory M. Redman, James D. Gardner, Craig S. Scott, and Dennis R. Braman Royal Tyrrell Museum of Palaeontology, P.O. Box 7500, Drumheller AB T0J 0Y0, Canada

Corresponding author: Cory M. Redman (e-mail: corymredman@gmail.com) 


\begin{abstract}
:
The Frenchman and Ravenscrag formations of southwestern Saskatchewan, Canada, record an apparently continuous sequence of nonmarine clastic sediments across the CretaceousPaleogene (K-Pg) boundary. Extensive exposures of these fossil-rich sediments occur in the Frenchman River Valley, near the towns of Ravenscrag, Eastend, and Shaunavon, and have been a focus of study since the 1970s. Despite this long history of investigation, a comprehensive account of the geographic and stratigraphic positions of many of the significant fossil localities has yet to be published. Given this state of affairs, the goals of this paper are to 1) document the geographic locations, stratigraphic positions, and lithologies of eleven key vertebrate microfossil localities, including several new localities that have been recently discovered and 2) provide an update on the status of these fossil localities, the majority of which have not been sampled in the last 20 years. Four fossil localities are known from the lower Paleocene Ravenscrag Formation, all of which are Puercan in age: Rav W-1 (Pu2), French Fry (Pu1), Croc Pot (?Pu2), and Pine Cree (?Pu2). With the exception of Rav W-1, which has since been lost as a consequence of quarry reclamation, all of the Ravenscrag Formation localities remain accessible and continue to be productive. Seven vertebrate microfossil localities from the upper Maastrichtian Frenchman Formation are reported here, all of which are Lancian in age: Long Fall, Fr-1, By Gar Gap, Hairpin, Wounded Knee, Wounded C, and Gryde. With the exception of Long Fall and Wounded Knee, which have been lost through reclamation or construction, all of the Frenchman Formation localities are accessible and remain productive.
\end{abstract}

Résumé: [translation to be provided by CJES] 
Keywords: Maastrichtian, Paleocene, microvertebrates, palynomorphs, mammals, terrestrial, Saskatchewan 


\section{Introduction}

The Frenchman and Ravenscrag formations of southern Saskatchewan, Canada, record an apparently continuous vertical sequence of nonmarine clastic sediments of latest Maastrichtian to late Paleocene, respectively (Dawson 1875; Davis 1918; McLearn 1929; Williams and Dyer 1930; Fraser et al. 1935; Furnival 1946; Kupsch 1956; Russell 1974; Krause 1977; Johnston 1980a; Lerbekmo 1985; Fox 1989; McIver and Basinger 1993; Lerbekmo et al. 1996; Tokaryk 1997; McIver 2002; Fox et al. 2007; Braman and Sweet 2012; Bamforth et al. 2014). These deposits have long been recognized as richly fossiliferous, particularly in the southwestern corner of Saskatchewan, where dozens of fossil localities document assemblages of plants, invertebrates, and vertebrates of latest Cretaceous and early Paleocene age. G.M. Dawson collected the first dinosaur bones in the Killdeer Badlands, from what is now recognized as the Frenchman Formation in the East Block of Grasslands National Park (Dawson 1875), as well as the first plant fossils from what is now recognized as the Ravenscrag Formation in Porcupine Creek and in the vicinity of Wood Mountain, Saskatchewan (Dawson 1875). Extensive exposures of the Frenchman and Ravenscrag formations, including the type areas (Furnival 1946; Hendry 1990), occur in the Frenchman River Valley, on the southeastern flank of the Cypress Hills, near the village of Ravenscrag and the towns of Eastend and Shaunavon (Fig. 1). This area has been a focus of geological and paleontological study for over a century (e.g., Dawson 1875; Bamforth et al. 2014), due in large part to the Frenchman and Ravenscrag formations being exposed in a series of near-continuous outcrops and isolated buttes, an abundance of fossils, and the presence of the Cretaceous-Paleogene (K-Pg) boundary claystone at multiple locations throughout the area. The K-Pg boundary claystone is a geological marker 
for a mass extinction event some 66 million years ago that resulted most famously in the extinction of non-avian dinosaurs, but significantly impacted other marine and nonmarine fauna and flora as well (Russell 1975; Alvarez et al. 1980; Clemens et al. 1981; Russell 1984; Sloan et al. 1986; Keller 1989; Archibald and Bryant 1990; Sheehan and Fastovsky 1992; Hurlbert and Archibald 1995; Markwick 1998; Lillegraven and Eberle 1999; Sheehan et al. 2000; Alegret et al. 2001; Hartman et al. 2002; Archibald and Fastovsky 2004; Wang and Dodson 2006; Wilf et al. 2006; Lloyd et al. 2008; Nichols and Johnson 2008; Barrett et al. 2009; Sessa et al. 2012; Renne et al. 2013; Wilson et al. 2014).

The Western Interior of North America is the only region on the globe known to preserve a continuous, or nearly continuous, terrestrial record that produces vertebrate fossils across the K-Pg boundary. Within the Western Interior, terrestrial deposits of latest Maastrichtian and earliest Paleocene age in Montana and North Dakota, U.S.A., are of particular importance, because they represent some of the best studied records of the K-Pg mass extinction, and thus form the basis for much of our understanding of this global extinction event in the terrestrial realm (e.g., Hartman et al. 2002; Archibald and Fastovsky 2004; Nichols and Johnson 2008; Gardner and DeMar 2013; Archibald 2014; Wilson et al. 2014). Although less well studied, nonmarine K-Pg records in Alberta and Saskatchewan (Fig. 2) provide unique opportunities to test many of the K-Pg extinction models that have been developed on the basis of geological and paleontological records in Montana and North Dakota (Lillegraven 1969; Johnston 1980a; Johnston and Fox 1984; Fox 1989; Fox 1990, 2002, 2005; Storer 1991; Sweet 1994; Sweet and Braman 1992; Gao and Fox 1996; Braman et al. 1999; Braman and Sweet 1999; Sweet et al. 1999; Fox et al. 2007; Therrien et al. 2007; Fox and Scott 2011). One long term research goal of $\mathrm{K}-\mathrm{Pg}$ boundary studies is to examine survivorship, extinction, and recovery patterns of terrestrial 
vertebrates from multiple basins at different latitudes, and from a wide range of habitats, in order to better understand this critical biological transition in Earth history. This study represents an important first step towards achieving this goal, by properly documenting for the first time the lithologies, stratigraphic positions and relationships, and geographic locations of eleven (four early Paleocene and seven latest Maastrichtian) key vertebrate microfossil localities in southwestern Saskatchewan (Fig. 1).

Vertebrate microfossil localities, or microsites, are accumulations of abundant $(>100)$, small-sized (1-100 mm), disarticulated skeletal elements such as teeth, scales, and bones (Eberth 1990; Eberth et al. 2007; Rogers and Brady 2010). Vertebrate microfossil assemblages are important for reconstructing ancient ecosystems, primarily because they document a diverse range of species of various body sizes that likely occupied a variety of habitats, and as such provide important data about local environments (Brinkman 1990; Jamniczky et al. 2003; Brinkman et al. 2004; DeMar and Breithaupt 2006; Sankey and Baszio 2008; Rogers and Brady 2010).

Investigations into changes in terrestrial vertebrate microfossil assemblages across the KPg boundary in southwestern Saskatchewan began in the mid-1970s, when field parties from the University of Alberta Laboratory for Vertebrate Paleontology (UALVP) discovered the first fossil mammal teeth near the village of Ravenscrag (Johnston 1980a, b; Johnston and Fox 1984). The UALVP, Royal Saskatchewan Museum (RSM), and other institutions subsequently discovered additional fossil localities in the upper parts of the Frenchman Formation and lower parts of the Ravenscrag Formation in the Ravenscrag-Eastend-Shaunavon area (e.g., Russell 1974; Johnston 1980a, 1980b; Johnston and Fox 1984; Tokaryk 1986, 1997; Fox 1989; Storer 1991; Tokaryk and Bryant 2004; Brown et al. 2011; Bamforth et al. 2014). Despite this rich 
history of collecting and study, a comprehensive account of the stratigraphic positions, geographic locations, and general lithologies has yet to be published for many of the important vertebrate microfossil localities from the Frenchman and Ravenscrag formations. This paper focuses on eleven key vertebrate microfossil localities (four from the earliest Paleocene and seven from the latest Maastrichtian) that are of historical significance and have yielded wellpublished assemblages, as well as several recently discovered, productive microsites that promise to provide important data in future studies. A complete review of all known vertebrate microfossil localities in the study area is beyond the scope of this paper. The Frenchman and Ravenscrag formations crop out over an extensive area in the Ravenscrag-Eastend-Shaunavon area, and although both formations have been studied by researchers from numerous institutions over the decades (e.g., UALVP, RSM, Royal Tyrrell Museum of Palaeontology (RTMP), Royal Ontario Museum (ROM), McGill University, and University of Lancaster), the majority of the known microsites are poorly sampled or unpublished. The goals of our paper are to 1) document the stratigraphic positions, geographic locations, and lithologies of eleven key vertebrate microfossil localities from the Ravenscrag-Eastend-Shaunavon area (Fig. 1), including several new localities that have been discovered recently and 2) provide an update on the status of those same localities, some of which have not been sampled in over 20 years and several have only recently been relocated.

\section{Regional geology}

The Frenchman and Ravenscrag formations were deposited primarily in the northern parts of the Williston Basin and a small part of the Alberta Syncline (Furnival 1946; Kupsch 1956; Russell 1974; Catuneanu and Sweet 1999; Lerbekmo and Sweet 2000; Lerbekmo and 
Braman 2002). Both formations intermittently crop out in a broad band across southern Saskatchewan and southeastern Alberta. The Frenchman Formation is the uppermost of five Maastrichtian age rock units in southern Saskatchewan (Fig. 2); in ascending order, the others are the Bearpaw, Eastend, Whitemud, and Battle formations (Fraser et al. 1935; Furnival 1946; Johnston 1980b; Russell 1974; McIver 2002). The type area for the Frenchman Formation is along the north side of the Frenchman River, from west of Ravenscrag to east of Saskatchewan Highway 37 (Hendry 1990). In the Ravenscrag-Eastend-Shaunavon area, the Frenchman Formation ranges in thickness from 8-68 meters and thickens to the east. The formation consists of two distinct, but informally recognized facies: a sand-dominated facies and a clay-dominated facies (Furnival 1946; Kupsch 1956; Russell 1974; McIver 2002; Bamforth et al. 2014). The sand-dominated facies consists largely of medium- to fine-grained quartz and lithic sandstones that are cross-bedded, poorly cemented with locally bearing indurated masses, and are intercalated with clay and silt lenses. Colors range from olive-green to salt and pepper to yellowish-brown. The clay-dominated facies consists of greyish-green to purple bentonitic clays and siltstones, although fine-grained sands are intercalated throughout. The sand-dominated facies can lie below, at the same level as, or above the clay-dominated facies, sometimes making it difficult to distinguish sediments of the Frenchman Formation from those of the overlying Ravenscrag Formation or the underlying Battle Formation (Furnival 1946; Kupsch 1956; Russell 1974; McIver 2002; Bamforth et al. 2014). The base of the Frenchman Formation is marked by an erosional unconformity and typically sits on the dark bentonitic mudstones of the Battle Formation, but can cut down into the marine shales of the Bearpaw Formation. The Frenchman Formation typically is conformably overlain by the Ferris (No. 1) Coal Seam, which is the lowest coal within the Ravenscrag Formation. The K-Pg boundary, complete with an iridium-enriched 
boundary claystone and a sequential transition in palynomorphs, occurs immediately below or within the Ferris Coal Seam (Lerbekmo et al. 1987; Braman and Sweet 2012). Sediments of the Frenchman Formation are considered to have been deposited in a broad meandering river valley. Studies of the fossil megaflora suggest that the Frenchman Formation was deposited in subtropical to warm-temperate environments showing marked seasonality, representing lowland forests characterized by an open canopy dominated by deciduous conifers and a mid-canopy and understory dominated by angiosperms (McIver 2002; Bamforth et al. 2014). At its thickest, the Frenchman Formation is thought to represent approximately half a million years or less of time. The unit documents a diverse vertebrate assemblage of Lancian age (Lerbekmo 1985, 1987; Fox 1989; Storer 1991; Cifelli et al. 2004; Kielan-Jaworowska et al. 2004; Fox et al. 2007; Gardner and DeMar 2013). Lancian refers to the final North American Land Mammal Age (NALMA) of the Late Cretaceous; NALMAs are biochronologic units representing discrete intervals of time based on the evolution of fossil mammals in North America (e.g., Russell 1975; Cifelli et al. 2004; Woodburne 2004).

The only formation of Paleocene age in southern Saskatchewan is the Ravenscrag Formation (Davis 1918; McLearn 1929; Fraser et al. 1935; Furnival 1946; Russell 1974; Krause 1977; McIver and Basinger 1993), a unit that ranges in thickness from 7-69 meters in the Ravenscrag-Eastend-Shaunavon area. The Ravenscrag Formation consists of interbedded clays, silts, sands and lignites, and is informally considered to be composed of two facies, a lower grey facies and an overlying buff facies (Furnival 1946; Russell 1974; McIver and Basinger 1993). The grey facies is dominated by greyish brown siltstone and claystones, with occasional rustycolored concretionary sandstones. The buff facies is dominated by siltstone or fine-grained sandstone with intercalated beds of grey clay and lignite. The type section for the Ravenscrag 
Formation is on the west end of Ravenscrag Butte (Fig. 1), where the grey facies comprises the lower 38 meters of the formation and the upper buff facies is less than 31 meters thick (Furnival 1946; McIver 1989; McIver and Basinger 1993). The Ravenscrag Formation is unconformably overlain by the Eocene-Miocene age Cypress Hills Formation or by Quaternary deposits. Sediments of the Ravenscrag Formation are considered to have been deposited in a broad meandering river valley, with the presence of broad, low-lying back waters (McIver 1989, 2002). Studies of the fossil megaflora suggest that the Ravenscrag Formation was deposited in a mesothermal, humid climate with abundant rainfall throughout the year and little to no frost, representing broad leaf deciduous forests characterized by well-defined canopy and subcanopy levels and an herbaceous understory (McIver and Basinger 1993). The Ravenscrag Formation is estimated to represent 1-1.5 million years of deposition in the Ravenscrag-Eastend-Shaunavon area and yields a vertebrate assemblage of Puercan (Pu1-3) age (Johnston 1980b; Johnston and Fox 1984; Lerbekmo 1985; Fox 1989, 1990; Storer 1993; Lofgren et al. 2004; Gardner and DeMar 2013). Puercan (Pu) refers to the first NALMA of the Paleogene and is divided into three biozones (i.e., $\mathrm{Pu} 1, \mathrm{Pu} 2$, and $\mathrm{Pu} 3$ ), all of which are defined by the first appearance of unrelated mammalian taxa (e.g., Lofgren et al. 2004).

\section{Materials and methods}

Locality accounts are provided from west-to east for eleven key vertebrate microfossil localities in the Ravenscrag-Eastend-Shaunavon area (Fig. 1). Four microsites are in the lowermost Paleocene portion of the Ravenscrag Formation and seven are in the uppermost Maastrichtian Frenchman Formation. Locality accounts for each vertebrate microsite consist of geographic location, photographic documentation (see online supplement), stratigraphic position, 
sedimentological description of the fossil-producing horizon, and a summary of collection and publication history. Stratigraphic sections included in this study were measured using the pace and compass method with a two meter long Jacob's staff and a side mounted Abney level.

Trenches were dug for the entire vertical extent of each section and sedimentological descriptions were made from these freshly exposed, unweathered rock surfaces. The RavenscragEastend-Shaunavon area has been subjected to extensive block faulting and slumping, which is often difficult to detect without sufficient outcrop (Russell 1948; F. McDougall, pers. comm. 2014). In order to overcome this, stratigraphic sections where measured on a single, vertical slope or composite sections were built by following bedding planes for a distance of less than 400 meters. The composite section along Highway 633 is the only section in this study where neither of these methods could be employed, due to exposures largely being limited to road cuts. This section was constructed using the pace and compass method, but it was not possible for trenches to be dug along the entire length of the section or for the composite sections to be built by following bedding planes. Grain size was determined using a 10x hand lens and a grain size chart. Color(s) of a bed were determined using the Munsell Color System (e.g., light olive gray5Y 5/2). Figure 4 depicts symbols used in the stratigraphic sections. All beds of the Frenchman and Ravenscrag formations described herein were considered to be horizontal or nearly horizontal when measuring the stratigraphic sections. Palynomorph samples were collected from sections containing the Pine Cree, Croc Pot, and Fr-1 microsites in an attempt to better refine the relative ages of those microsites, since their stratigraphic positions relative to the K-Pg boundary could not be directly measured. Palynomorph samples are curated in the RTMP permanent collections. 
High precision GPS coordinates and elevations of fossil localities, K-Pg boundary claystones, and the bottom and top of each measured stratigraphic section were taken using a hand held Ashtech MobileMapper 100 unit. High precision GPS coordinates were used to confirm measured stratigraphic thicknesses and to determine the stratigraphic position of fossil localities relative to the K-Pg boundary using elevations, if direct measurement could not be done using the pace and compass method. RSM permits mandate that precise locality data cannot be reported here; GPS coordinates of all localities included in this report may be made available to qualified investigators through the RSM.

\section{Locality accounts}

\section{Croc Pot (Ravenscrag Formation, early Paleocene, ?Pu2)}

The Croc Pot microsite occurs in the Ravenscrag Formation near the top of a small hill, located five kilometers west of the village of Ravenscrag (Fig. 3; online supplemental Fig. 1). Croc Pot is in a cross-bedded quartz sandstone of lower-medium grain size $(250-350 \mu \mathrm{m})$, poorly cemented, and moderately yellow (5Y 7/6) color (Fig. 5). The fossil-producing horizon contains poorly sorted, abundant, rounded clay clasts and limonite concretions, but the majority of the sandstone bed is very well sorted. The fossil-producing horizon varies laterally in thickness to a maximum of 66 centimeters. The sandstone bed containing the Croc Pot microsite is unconformably capped by a matrix-supported conglomerate of the Cypress Hills Formation (Fig. 5).

Six palynomorph samples were collected from the Croc Pot section (Fig. 5). The uppermost sample was taken 1.5 meters below the Croc Pot microsite and is essentially barren. The uppermost pollen sample is considered to occur in the Ravenscrag Formation, primarily 
because informative palynomorph assemblages are only recovered at sporadically intervals throughout this formation and generally produce a more depauperate assemblage when compared with those from the Frenchman Formation (Braman and Sweet 1999). The lower five samples were taken at various levels farther below the Croc Pot microsite (Fig. 5) and each had excellent recovery yielding a diverse assemblage. Each sample contains abundant dinoflagellates, indicating fully marine conditions during deposition. The presence of Scollardia trapaformis Srivastava, 1966 and Mancicorpus gibbus Srivastava, 1968 are noteworthy, because both species are characteristic of the Scollardia trapaformis Biozone (Srivastava 1970), a biozone that is restricted to a short interval of time in the latter part of the early Maastrichtian (Braman and Sweet 1999). The Scollardia trapaformis Biozone has been identified in the Carbon Member of the Horseshoe Canyon Formation of Alberta and in the Eastend Formation of Saskatchewan. Judging by its palynological content, at this locality the Ravenscrag Formation unconformably overlies the Eastend Formation, with the Frenchman, Battle, and the Whitemud formations all being absent.

Determining the stratigraphic position of the Croc Pot microsite relative to the K-Pg boundary is not possible at this time, because the closest outcrop containing the Ferris Coal Seam is 11 kilometers to the east in the type section for Ravenscrag Formation on Ravenscrag Butte. The obvious color change near the top of the hill and a lack of any other lithological markers (online supplemental Fig. 1A) led Johnston (1980b) to suggest that Croc Pot occurs in the buff facies of the Ravenscrag Formation. Johnston (1980b) further suggested that Croc Pot occurs in part of a down-thrown block, which if restored to its proper stratigraphic position would be higher in the Ravenscrag Formation. Although Johnston (1980b) provided no evidence for such faulting, we note there is a distinct break in topography along the ridge line between Croc Pot 
and farther to the east at the old Medicine Hat Brick and Tile (MHBT) Quarry that contained the Rav W-1 and Long Fall microsites (see next account and online supplemental Fig. 1B, C). Given these realities, the stratigraphic position of the Croc Pot microsite relative to the K-Pg boundary remains ambiguous for the time being. Mapping the formational contacts from Ravenscrag Butte to the area around the village of Ravenscrag, including the section at Croc Pot, is a goal for future work.

Croc Pot was discovered in 1979 and even though it is an extremely rich microsite, little has been published on the specimens to date (Johnston 1980a; Fox 1990; Spivak 1997). Fox (1990) included a preliminary list of mammalian taxa and using a two-fold division of the Puercan NALMA considered the fauna to be P2 in age, younger than that of the Rav W-1 locality $1.3 \mathrm{~km}$ to the northeast. Fox's (1990) age estimate for Croc Pot was based in part on the presence of the taeniolabidid multituberculate Taeniolabis taoensis in the local fauna. In their study of a new species of the purgatoriid primate Purgatorius from the Rav W-1 microsite (see next account), Fox and Scott (2011) noted that the fragmentary taeniolabidid specimens originally identified as pertaining to an unidentified species of Taeniolabis (and that Lofgren et al. (2004) cited as evidence for a late Puercan (Pu3) age for that locality) were better interpreted as belonging to an as yet unidentified species of Catopsalis, close in size and perhaps conspecific with C. waddleae Buckley, 1995. Our examination of the taeniolabidid material from Croc Pot suggests that the same situation may apply to these specimens as well, casting some uncertainty on the age of the fauna. Croc Pot is slightly higher in elevation than Rav W-1 (Fox 1990), and although more taxonomically diverse, the fauna does not include any first appearance or index taxa indicative of a late Puercan (Pu3) age (Lofgren et al. 2004). The absence of such taxa, combined with the strong similarity in taxonomic content with Rav W-1 (see Fox 1990), and 
acknowledging that the Croc Pot fauna is largely unstudied, we tentatively assign a Pu2 age for this faunal assemblage, with the expectation that this estimate will be further refined once the mammalian fauna from Croc Pot becomes better known.

In addition to the mammal specimens, Spivak (1997) noted that skeletal elements from sharks, rays, gar, amphibians, turtles, lizards, crocodiles, and champsosaurs have also been recovered from Croc Pot. Croc Pot was bulk sampled in 1979, 1980, 1996, and 1997 by the UALVP, and again in 2008 by the RTMP.

\section{Rav W-1 (Ravenscrag Formation, early Paleocene, Pu2) and Long Fall (?Frenchman Formation, latest Maastrichtian, Lancian)}

The Rav W-1 and Long Fall microsites, both within the Medicine Hat Brick and Tile (MHBT) Quarry, were exposed and subsequently destroyed during quarrying activities of the Medicine Hat Brick and Tile Company (online supplemental Figs. 1B, C, and 2), a commercial clay quarrier that operated in the area about 1.3 kilometers northeast of Croc Pot (Fig. 3). Rav W-1 was originally discovered in 1974 when fossil gar scales were found on a grassy slope adjacent to the working quarry face; the first mammal fossils were found later that summer (Johnston and Fox 1984). The Rav W-1 fossil-producing horizon occurred in a clay-pebble lag deposit, 0.34 meters thick and approximately 3.4 meters from the base of laterally discontinuous, indurated lenses of lithic, medium-grained sandstone (Johnston and Fox 1984). In 1975, it was discovered that the Rav W-1 fossil-producing horizon extended laterally from the grassy slope onto the nearby face of the quarry wall, where it increased in thickness to approximately one meter (Johnston and Fox 1984). The discontinuous, indurated sandstone lenses above Rav W-1 
continued up section and graded into interbedded grey and buff clays and fine sands (Johnston 1980a). Rav W-1 was bulk sampled from 1975 to 1977 by the UALVP.

Rav W-1 is the type locality for the following mammalian taxa: Neoplagiaulax kremnus Johnston and Fox, 1984; Parectypodus armstrongi Johnston and Fox, 1984; Stygimys camptorhiza Johnston and Fox, 1984; “Microcosmodon" arcuatus Johnston and Fox, 1984; Oxyclaenus corax Johnston and Fox, 1984; Loxolophus schizophrenus Johnston and Fox, 1984; Bubogonia saskia Johnston and Fox, 1984; Litomylus orthronepius Johnston and Fox, 1984; Ravenictis krausei Fox and Youzwyshyn, 1994; and Purgatorius coracis Fox and Scott, 2011. By 1978 or 1979, ongoing quarry operations had destroyed the Rav W-1 fossil-producing horizon on the quarry face and the grassy slope, but in 1979 quarry operations exposed a second fossil-producing horizon dubbed Long Fall (Johnston and Fox 1984). This microsite occurred approximately 3.1 meters below Rav W-1 at the base of a heavily trough cross-bedded sandstone (online supplemental Fig. 2C) that sat unconformably on a thin greenish claystone (Johnston and Fox 1984). The fossil-producing horizon was about 0.3 meters thick and extended laterally for over 2 meters (Johnston and Fox 1984). Long Fall was bulk sampled in 1979 and 1980 by the UALVP and was subsequently destroyed by quarry operations shortly thereafter (Johnston 1980b). Long Fall is the type locality for the following mammalian taxa: Stygimys cupressus Fox, 1989 (but see Lofgren et al. 2005) and Catopsalis johnstoni Fox, 1989 (but see Lucas et al. 1997). The MHBT Quarry was not bulk sampled again until 2008 by the RTMP. That was intended to be a preliminary visit, but the quarry was completely filled in and reclaimed in 2011 (online supplemental Fig. 1B versus C) before the RTMP was able to return to the area in October 2012. In 2008, the RTMP took a series of smaller bulk samples from the indurated and trough cross-bedded sandstones. Those samples yielded some vertebrate microfossils, but 
nothing as rich as the samples taken decades earlier by UALVP from the Rav W-1 and Long Fall fossil-producing horizons.

The formational affinity and relative age of the Long Fall microsite has been a subject of considerable debate, in large part because the Ferris Coal Seam is not present in the MHBT Quarry (online supplemental Fig. 2) or the surrounding area. Fox (1989) considered both the trough cross-bedded sandstones overlying Long Fall and the greenish shale underneath to be in the Frenchman Formation, and the indurated, siltier sandstones overlying Rav W-1 to be in the Ravenscrag Formation, with a disconformity separating the two sandstone bodies (see footnote in Johnston and Fox 1984, p. 216). In contrast, Lerbekmo (1985) considered that the fossilproducing horizons of Rav W-1 and Long Fall represented two different lenses of a single point bar deposit contained entirely within the Ravenscrag Formation. Lerbekmo (1985) interpreted the change in lithology from trough cross-bedded sandstones to indurated siltier sandstones as a continuous sequence, representing a progression from predominantly high-angle, cross-stratified, coarse channel-bottom sands to middle point bar style, low-angle laterally accreted deposits of finer sands and silts. Lerbekmo (1985) suggested that the Long Fall microsite occurred in a basal lag and that the Late Cretaceous vertebrate fossils recovered from Long Fall had been reworked from the underlying Battle Formation, which was represented in the MHBT Quarry by the greenish shale immediately below the trough cross-bedded sandstone containing the Long Fall microsite (online supplemental Fig. 2C).

On the basis of the reported disconformity between the two sandstone bodies (Johnston and Fox 1984), as well as the vertebrate assemblages documented at both microsites, Fox (1989, 1990) reaffirmed a Lancian age for the Long Fall fauna and an early Paleocene (P1, in Fox's two-fold division of the Puercan) age for the Rav W-1 fauna. Fox (1989) noted that Long Fall 
preserved dinosaur teeth (e.g., theropod, ankylosaur, and ceratopsian) and specimens of the marsupials Alphadon and Pediomys, all being taxa that are restricted to the Late Cretaceous, whereas Rav W-1 contained mammalian taxa that were indicative of an early Paleocene age and lacked any indication of dinosaur taxa. Taxa shared between both microsites (e.g., Mesodma, Cimexomys, Cimolestes) have previously been shown to span the K-Pg boundary. Fox (1989) further argued that there were no differences in the color or preservational state among any of the vertebrate specimens from Long Fall that might be suggestive of significant time-averaging, and that potential sources for reworked Late Cretaceous vertebrates (e.g., Battle and Whitemud formations) are largely barren of fossils, both in Saskatchewan and Alberta.

A distinct change in color and a potential change in the bedding structure can be seen in the numerous photos taken of the MHBT Quarry walls between 1975 and 2008 (e.g., online supplemental Fig. 2). We have not found a close-up photograph of the disconformity reported by Johnston and Fox (1984) or a detailed sedimentological description or measured stratigraphic section for the MHBT Quarry. The presence of a disconformity between Rav W-1 and Long Fall microsites was not published until 1984 (see footnote in Johnston and Fox 1984 p. 216) and it is unclear whether that disconformity was exposed in the MHBT Quarry when Lerbekmo was collecting data for his 1985 publication. The walls of the MHBT Quarry were continuously being excavated during its operation, stepping farther to the north and west, with lateral changes in the sedimentology and the fossil-producing horizons being exposed and subsequently destroyed. As such, the quarry walls could have changed significantly even in the short time between when the UALVP made their fossil collections and when Lerbekmo visited the quarry, meaning that the two research parties may not have examined the same deposits or features. 
Several publications provided a brief sedimentological description of the MHBT Quarry (Johnston 1980a; Johnston and Fox 1984; Fox 1989, 1990; Fox et al. 2010; Fox and Scott 2011). Fox (1989, fig. 5) provided a stratigraphic column for the MHBT Quarry, but its accuracy cannot be verified due to reclamation of the quarry. The MHBT Quarry was sampled for palynomorphs and magnetostratigraphy, but those samples were inconclusive for determining the position of the Frenchman-Ravenscrag formational contact (Lerbekmo 1985). Unfortunately, in 2011 the MHBT Quarry was completed filled in, and we were unable to locate an alternative section in the immediate vicinity of the old quarry.

\section{Fr-1 (Frenchman Formation, latest Maastrichtian, Lancian)}

The Fr-1 microsite occurs in the Frenchman Formation about two kilometers to the northeast of the old MHBT Quarry, on a small isolated knoll (Fig. 3; online supplemental Fig. 3). The microsite occurs in a cross-bedded, quartz sandstone with upper-fine to lower-medium grain size $(177-250 \mu \mathrm{m})$ and a dark yellowish orange (10YR 6/6) to light brown (5YR 5/6) color (Fig. 6). The sandstone is very well sorted, but contains occasional pockets of lithics, rare lenses of siltstone clasts, and carbonized plant fragments (Fig. 6). At Fr-1, the Frenchman Formation is only 2.3 meters thick. It cuts down into a 1.2 meter thick exposure of the Battle Formation that, in turn, rests conformably on 6.2 meters of the whitish-gray kaolinized sands of the Whitemud Formation that forms the base of the knoll (online supplemental Fig. 3). Because of limited exposure at Fr-1, a more nearly complete measured section was described using the hill immediately to the north. The position of the Frenchman-Ravenscrag formational contact in the Fr-1 area could not be determined, because the Ferris Coal Seam is not preserved in the area, part 
of the section is heavily grassed over, and the five palynomorph samples had extremely poor recovery and did not yield any age-diagnostic palynomorphs (Fig. 6).

Fr-1 was discovered in 1977 and yielded the first Mesozoic mammals described from Saskatchewan, as well as the first occurrence of condylarths (Protungulatum sp.cf. P. donnae and a possible periptychid) from the Late Cretaceous (Johnston 1980a; Fox 1989). In addition to the mammals, Johnston (1980a) also documented the occurrences of Myledaphus, Lepisosteus, Amia, Scapherpeton, turtles, champsosaurs, crocodiles, and dinosaurs (including ceratopsians, ornithopods, and theropods). Fr-1 was bulk sampled in 1977 and 1979 by the UALVP, and was only recently relocated and bulk sampled by the RTMP in 2014.

\section{Pine Cree (Ravenscrag Formation, early Paleocene, ?Pu2)}

The Pine Cree microsite occurs in the Ravenscrag Formation and is located in Pine Cree Regional Park, about 12 kilometers northeast of Eastend along Highway 633 (Figs. 1, 7). The microsite occurs in a small cut-bank on the east side of a creek, near the south end of the park (online supplemental Fig. 4). Exposures of the Ravenscrag Formation are limited (7 meters vertical extent) in the park and coal is not present in the immediate area. Because of these limitations, a more nearly complete section was also measured and described using strata exposed in road cuts along a two kilometer stretch of Highway 633, between the South Fork Coulee and northwards to the top of the hill near the entrance to Pine Cree Regional Park.

The Pine Cree microsite occurs at the top of a cross-bedded quartz sandstone with uppervery fine to lower-fine grain size $(88-177 \mu \mathrm{m})$ and yellowish-gray $(5 \mathrm{Y} 7 / 2)$ color (Fig. 8). The fossil-producing horizon is $21 \mathrm{~cm}$ thick and contains abundant carbonized wood fragments, siltstone clasts, root traces, and molluscs (Russell 1974). Russell (1974) thought that strata at the 
Pine Cree microsite most closely resembled the buff facies of the Ravenscrag Formation, and on the basis of topographic and elevation positions he concluded that the microsite occurred approximately 37 meters above the base of the formation, near the grey-buff facies transition. The K-Pg boundary claystone is present at the base of the Ferris Coal Seam exposed along Highway 633. Using elevation readings of the boundary claystone and the Pine Cree microsite, we place the microsite lower in the formation at approximately 18 meters above the K-Pg boundary. However, there is 1.6 kilometers of covered area between the Pine Cree microsite and the closest exposures of the Ferris Coal Seam and faulting is known to be present in the area, so the presence of faulting between the two cannot be excluded (F. McDougall, pers. comm. 2014). Pine Cree was discovered in 1971 and produced the first mammal specimen to be described from the Ravenscrag Formation of Saskatchewan (Russell 1974). The holotype of the condylarth Carcinodon aquilonius Russell, 1974 and two neoplagiaulacid multituberculate teeth have been collected from the Pine Cree microsite (Fox 1990). Based on the presence of $C$. aquilonius, Fox (1990) tentatively suggested an early Puercan age (P1, in Fox's two-fold division of the Puercan) for the local fauna. C. aquilonius has since been discovered at localities of middle to late Puercan $(\mathrm{Pu} 2 / \mathrm{Pu} 3)$ age in other parts of the Western Interior (e.g., Hartman et al. 1989; Wilson et al. 2014), making the age assessment of Pine Cree less certain. In an attempt to better refine the age estimate for the Pine Cree microsite, five palynomorph samples were collected and examined (Fig. 8). Recovery in the samples was fair to good, but stratigraphically significant species in the samples were very rare. A single specimen of Momipites wyomingensis Nichols and Ott, 1978 was recovered in the uppermost sample. The rarity of species of Momipites and the lack of palynomorphs characteristic of the earliest Paleocene in all the samples suggest that the strata at Pine Cree occur in the "rare Momipites subzone" in the lower 
part of the Momipites Biozone of Lerbekmo and Sweet (2000, fig. 21), which correlates with the middle to late part of the Puercan (Pu2/Pu3). We tentatively assign the Pine Cree mammal fauna a Pu2 age, but acknowledge that the estimate will almost certainly be refined once additional mammal and pollen data become available. The Pine Cree microsite was sampled by the ROM in 1972, the RSM in 1977, the UALVP in 1979, and the RTMP in 2012.

\section{By Gar Gap (Frenchman Formation, latest Maastrichtian, Lancian)}

The By Gar Gap microsite occurs 14 meters below the base of the Ferris Coal Seam in the Frenchman Formation at a road cut along the east side of Highway 633, about six kilometers north of the junction with Highway 13 (Figs. 1, 7; online supplemental Fig. 5). By Gar Gap is in a clast-supported conglomerate composed primarily of siltstone, with quartz sandstone lenses of upper-fine to lower-medium (177-350 $\mu \mathrm{m})$ grain size (Fig. 8). Wood fragments are particularly common. The fossil-producing horizon is up to 87 centimeters thick and extends laterally for at least three meters.

By Gar Gap was discovered in 1979 and is a richly fossiliferous locality dominated ( $>85 \%$ of identifiable specimens) by ganoid scales of the gar Lepisosteus. Also present are incomplete skeletal elements of mammals, dinosaurs, crocodylians, turtles, and actinopterygians. By Gar Gap was bulk sampled in 1979 by the UALVP and in 2008 by the RTMP, but its assemblage remains unpublished.

\section{Hairpin (Frenchman Formation, latest Maastrichtian, Lancian)}

The Hairpin microsite occurs in the Frenchman Formation, 30 kilometers southwest of Shaunavon at the head of Chambery Coulee (Figs. 1, 9; online supplemental Fig. 6). Chambery 
Coulee has been an area of focus by the RSM and is best known for having produced a partial Tyrannosaurus rex skeleton, nicknamed "Scotty" (McIver 2002; Tokaryk and Bryant 2004;

Currie and Shychoski 2009; Paulina Carabajal and Currie 2009; Bamforth et al. 2014) and an incomplete dentary of the therian mammal Nanocuris improvida Fox et al., 2007. The Hairpin microsite occurs in a cross-bedded lithic sandstone with lower- to upper-fine $(125-250 \mu \mathrm{m})$ grain size (Fig. 10). The sandstone bed is very poorly cemented and very well sorted, except at its base where small lenses of clay clasts are present. The fossil-producing horizon is at least $55 \mathrm{~cm}$ thick and occurs 17 meters below the base of the Ferris Coal Seam (Fig. 10).

Hairpin was bulk sampled by the RSM in 1996, 1997, and 2001, and by the RTMP in 2013. Hairpin contains a vertebrate assemblage similar in composition to those seen at other Lancian microfossil localities in the Frenchman Formation (i.e., dinosaurs, mammals, lizards, amphibians, turtles, crocodiles, sharks, and fish). Other microvertebrate and macrovertebrate localities are known from the Chambery Coulee area (Tokaryk et al. 2009; Bamforth 2013), but these are not included in this study, because they either are too poorly sampled or are currently under study by the RSM.

\section{French Fry (Ravenscrag Formation, early Paleocene, Pu1)}

The French Fry locality occurs in the Ravenscrag Formation, 34 kilometers south of Shaunavon, at a large road cut along the east side of Highway 37, where the highway begins to descend into the Frenchman River Valley (Figs. 1, 9; online supplemental Fig. 7). French Fry occurs in a black (N1.5) fissile shale, 84-100 centimeters above the K-Pg boundary claystone (Fig. 11) and is thought to have been deposited in a lacustrine environment (Fox 2002). The 
fossil-producing horizon is less than 129 centimeters thick. Fossils at French Fry are rare, but extremely well preserved.

French Fry was discovered in 1986, but hand quarrying did not begin until the late 1990s when field parties from the UALVP made a small collection of vertebrate specimens, including an incomplete dentary of the multituberculate Mesodma sp., cf. M. thompsoni, as well as fragmentary scales, vertebrae, and teeth from several kinds of actinopterygians (Fox 2002). Three nearly complete and well-preserved champsosaur skeletons (RSM P2697.1, RSM P2900.1, and RSM P2624.1) were recovered from roughly the same stratigraphic level about 50-100 meters to the southeast, but these have not yet been described. French Fry has only been hand quarried; it has not been bulk sampled and screen washed. French Fry is of particular interest, because of its position low in the Ravenscrag Formation, its unique depositional environment, and is one of the few fossil localities in the Ravenscrag Formation to have produced nearly complete, articulated skeletons.

\section{Wounded Knee (Frenchman Formation, latest Maastrichtian, Lancian)}

The Wounded Knee microsite occurs in the Frenchman Formation about 160 meters to the southeast of French Fry, in the same Highway 37 roadcut (Figs. 1, 9; online supplemental Fig. 7). Remodeling of Highway 37 in 2003 and 2004 resulted in changes to the slope along the southern part of the roadcut (online supplemental Fig. 8A versus B). Although the French Fry locality and the K-Pg boundary were preserved, we have not been able to relocate the Wounded Knee microsite. It may be grassed over, have eroded away, or was inadvertently removed during construction. Wounded Knee occurred in a wind-deflated blowout consisting of thin, greenishgray sandstone in the upper part of the Frenchman Formation (Fox 1989). Vertebrate fossils were 
initially surface collected over a 100 square meter surface area, followed by bulk sampling and screen washing. Fox (1989) indicated that Wounded Knee occurred 25 meters below the K-Pg boundary. However, using the locality photograph published by Fox (1989, fig. 3; online supplemental Fig. 8) as a guide to the approximate location of Wounded Knee, we measured the stratigraphic position of the microsite to be 10-15 meters below the Ferris Coal Seam (Fig. 11).

Wounded Knee was discovered in 1979 and was bulk sampled by the UALVP from 1979-1981 and again in 1984. Wounded Knee is the type locality for the eutherian mammal Alostera saskatchewanensis Fox, 1989. The mammal and lizard portions of the assemblage have been published in detail (Fox 1989; Gao and Fox 1996). Fox (1989) also provided a list of nonmammalian vertebrates for the locality that includes chondrichthyans (Myledaphus, Lonchidion), actinopterygians (Belostomus, Kindleia, Lepisosteus, indeterminate teleosts), amphibians (indeterminate frogs, Albanerpeton, Scapherpeton, Opisthotriton, Prodesmodon, Habrosaurus), turtles (Trionyx), champsosaurs, lizards, the snake Coniophis, crocodiles, birds, and dinosaurs (including coelurosaur, carnosaur, hadrosaur, ankylosaur, and ceratopsian).

\section{Wounded C (Frenchman Formation, latest Maastrichtian, Lancian)}

Located 350 meters southeast of Wounded Knee, the Wounded C microsite occurs in the Frenchman Formation near the top of an abandoned road cut of an old roadway for Highway 37 (Figs. 1, 9; online supplemental Figs. 7, 9). The microsite sits at the base of a large, multi-story sandstone body. Wounded Knee is believed to occur at the top of the same sandstone body (Fig. 11). Wounded C occurs in a cross-bedded, lithic sandstone of upper-fine grain size (177-250 $\mu \mathrm{m})$ that is very well sorted, very poorly cemented, yellowish gray $(5 \mathrm{Y} 7 / 3)$ in color, and has 
moderately abundant limonite concretions at the base the sandstone (Fig. 11). The fossilproducing layer has a minimum thickness of 72 centimeters.

Wounded C was discovered by field parties from the RTMP in 2013 and an initial collection of 1087 kilograms of matrix was bulk sampled for screen washing. Although none of the material has been described, our preliminary observations of the sorted concentrate suggest the microsite documents a vertebrate microfossil assemblage of Lancian age, similar in its taxonomic composition to other contemporaneous localities in the area, including Wounded Knee.

\section{Gryde (Frenchman Formation, latest Maastrichtian, Lancian)}

The Gryde microsite occurs in the Frenchman Formation on the south side of the Frenchman River Valley, 3.4 kilometers south from Wounded Knee (Fig. 9) and to the west of Highway 37 (Fig. 9; online supplemental Fig. 10). This microsite occurs in an olive gray (5Y 4/1) siltstone containing abundant root traces and rare burrows (Fig. 12). The Gryde microsite is unique among vertebrate microfossil localities in the Ravenscrag-Eastend-Shaunavon area, because it occurs in a siltstone and is thought to represent a floodplain or overbank deposit (Storer 1991). The stratigraphic position of Gryde relative to the K-Pg boundary is uncertain, because the Ferris Coal Seam is not exposed in the vicinity. Storer (1991) considered the microsite to be somewhat stratigraphically lower than Wounded Knee. Based on the elevations of the Gryde microsite compared with the boundary claystone exposed on the north side of the Frenchman River Valley and assuming there is no significant vertical displacement due to faulting, we place the Gryde locality approximately 20 meters below the K-Pg boundary. 
Gryde was discovered in 1984 and has produced abundant mammalian specimens, including the holotypes of the multituberculate Parectypodus foxi Storer, 1991 and the marsupial Turgidodon petiminis Storer, 1991. To date, only the mammal (Storer 1991) and lizard (Gao and Fox 1996) components of the assemblage, as well as an isolated coracoid of the charadriiform bird Cimolopteryx have been published (Tokaryk and James 1989). Gryde also records a diverse assemblage of other vertebrates, including cartilaginous and bony fish, amphibians, and mesoreptiles (Storer 1991). The Gryde microsite was bulk sampled ( 1300 kilograms) in 1985 and 1986 by the RSM, but became inaccessible due to landowner restrictions. Changes in land ownership in the past few years allowed the RTMP to relocate the Gryde microsite in 2014 and collect a bulk sample of 1013 kilograms of matrix for screen washing.

\section{Discussion}

Regional correlation of the six stratigraphic sections measured for this study (Fig. 13) confirms the results of previous studies (Fraser et al. 1935; Furnival 1946; Russell 1974; McIver 2002) in showing that the Ravenscrag Formation in the Ravenscrag-Eastend-Shaunavon area is thickest at the west end of Ravenscrag Butte and thins both to the west and east. The Frenchman Formation thickens east of Eastend and is well exposed in the area south of Shaunavon where Highway 37 crosses the Frenchman River. The Battle, Whitemud, and Eastend formations are well exposed in the area from Ravenscrag to Eastend, but are largely absent farther east and south due to down cutting by the Frenchman Formation. In this study, the thickest section of the Ravenscrag and Frenchman formations was measured just east of Eastend along Highway 633.

In the Ravenscrag-Eastend-Shaunavon area, four fossil localities (Croc Pot, Rav W-1, Pine Cree, and French Fry) are known from the Ravenscrag formation (Fig. 13). One of those 
(Rav W-1) has been destroyed by quarry reclamation. French Fry is the lowest fossil locality in the Ravenscrag Formation and its stratigraphic position, approximately one meter above the KPg boundary, was directly measured from the Ferris Coal Seam that is well exposed in a road cut along Highway 37. The exact stratigraphic positions of Rav W-1 and Croc Pot relative to the KPg boundary cannot be determined, because the Ferris Coal Seam is not exposed in those areas, but both microsites can be confidently placed in the Ravenscrag Formation and assigned a middle Puercan age (Pu2 and ?Pu2, respectively). Although the Ferris Coal Seam is exposed near the Pine Cree microsite, there is not continuous exposure between the two, meaning the stratigraphic position of Pine Cree relative to the K-Pg boundary (estimated here as being 18 meters above the boundary) can only be tentatively placed using elevations of the boundary claystone and the microsite. However, the Pine Cree microsite can be tentatively assigned an early Paleocene age (?Pu2) on the basis of its mammalian and palynomorph assemblages. Three of the four microsites from the Ravenscrag Formation (Croc Pot, Rav W-1, and Pine Cree) occur in a cross-bedded sandstone of upper-very fine to lower-medium grain size $(88-350 \mu \mathrm{m})$ with abundant rounded mudstone clasts and the presence of iron concretions and wood fragments, suggesting that they are probably part of different channel deposits. What part of the channel (i.e., basal lag, point bar, etc.) each microsite comes from has not yet been determined, because sedimentary facies have not been identified and mapped out. The French Fry locality occurs in a black fissile shale that has been suggested to represent a lacustrine deposit, making it depositionally unique for the Ravenscrag Formation.

Seven microsites from the Frenchman Formation are presented in this study (Fig. 13). One microsite (Long Fall) has been destroyed as a result of quarry reclamation and another (Wounded Knee) may have been destroyed during road construction. Although the formational 
placement and age assessment of the now-inaccessible Long Fall microsite have been debated, the other six microsites are unequivocally placed in the Frenchman Formation and confidently considered to be Lancian in age. The stratigraphic positions of By Gar Gap, Hairpin, Wounded Knee, and Wounded C relative to the Ferris Coal Seam (i.e., K-Pg boundary) can all be determined by reference to the Ferris Coal Seam, which is exposed in each of the respective measured sections. The exact stratigraphic position of the Long Fall and Fr-1 microsites relative to the K-Pg boundary cannot be determined, because the Ferris Coal Seam is not exposed in those areas and the Long Fall microsite is no longer accessible. Although the Ferris Coal Seam is exposed on the north side of the Frenchman River Valley across from the Gryde microsite, there is three kilometers of distance between the two, meaning the stratigraphic placement of Gryde relative to the K-Pg boundary (20 meters below the boundary according to our study) can only be tentatively placed using elevations of the boundary claystone and the microsite. However, the Gryde microsite can be confidently assigned to a Lancian age on the basis of its vertebrate assemblage.

Six (Long Fall, Fr-1, By Gar Gap, Hairpin, Wounded Knee, and Wounded C) of the seven microsites in the Frenchman Formation occur in a cross-bedded sandstone of lower-fine to lower-medium grain size $(125-350 \mu \mathrm{m})$ with rare mudstone clasts, iron concretions, and wood fragments, suggesting that they are part of channel deposits. Though what part of a channel each microsite comes from has also not been determined. Gryde occurs in a siltstone that is suggested to represent a floodplain or overbank deposit, making it depositionally unique for the Frenchman Formation.

\section{Conclusion}


The K-Pg mass extinction represents one of five global scale extinction events that are known to have occurred during the history of life on Earth (Sepkoski 1996). While the timing and primary cause of this mass extinction event continue to be debated (e.g., Clemens et al. 1981; Hulbert and Archibald 1995; Sheehan et al. 2000; Archibald and Fastovsky 2004; Wang and Dodson 2006; Nichols and Johnson 2008; Archibald 2014), the geological and paleontological record of southern Saskatchewan will unquestionably play an important role in developing a better understanding of the changes in terrestrial vertebrate faunas during the time immediately before and after that extinction event (e.g., Russell 1974; Johnston 1980a; Johnston and Fox 1984; Fox 1989, 1990; Storer 1991; McIver and Basinger 1993; Gao and Fox 1996; McIver 2002; Bamforth et al. 2014). Despite the long history of paleontological and geological exploration in southwestern Saskatchewan, knowledge of this area remains limited and there is a wealth of opportunity for continued exploration and future studies. Publications to date have largely focused on palynomorphs (Lerbekmo 1985; Sweet et al. 1999; Braman and Sweet 2012) and mammals (Russell 1974; Johnston 1980a, b; Johnston and Fox 1984; Fox 1989, 1990; Storer 1991, 1993; Fox and Youzwyshyn 1994; Fox et al. 2007; Fox et al. 2010; Fox and Scott 2011), but there have also been key publications on lizards (Gao and Fox 1996), dinosaurs (Tokaryk 1986, 1997; Brown et al. 2011), and a short note on birds (Tokaryk and James 1989). Lissamphibian records from the Frenchman and Ravenscrag formations were recently included in a comprehensive review of North American Mesozoic and Paleocene occurrences (Gardner and DeMar 2013). The remainder of the fossil vertebrate assemblages has largely been reported in field guides (McKenzie-McAnally 1997) and conference abstract volumes (e.g., Tokaryk et al. 2009). Developing a comprehensive understanding of the fossil assemblages (i.e., vertebrates, invertebrates, and plants) from the Frenchman and Ravenscrag formations of southern 
Saskatchewan will help refine our understanding of the effects of the K-Pg extinction event on a local scale, and at a regional level will provide an important comparison of survivorship and extinction patterns with fossil assemblages of the Scollard Formation in southern Alberta (e.g., Lillegraven 1969) and the better studied assemblages of the Hell Creek and Fort Union formations in eastern Montana (e.g., Wilson et al. 2014) and southwestern North Dakota (e.g., Hartman et al. 2002) (Fig. 2).

In our opinion, two critical avenues of research worth pursuing in the RavenscragEastend-Shaunavon area are sedimentological studies and mapping of Maastrichtian and Paleogene formational contacts and unconformities. There are numerous faults in the area and outside of the Frenchman River Valley outcrops can be isolated and the number and thicknesses of the formations present in a given area can change over short distances $(<1 \mathrm{~km})$. Much of the pioneering geological research in southwestern Saskatchewan was done in the early to mid- $20^{\text {th }}$ century (Davis 1918; McLearn 1929; Williams and Dyer 1930; Fraser et al. 1935; Furnival 1946; Kupsch 1956; Russell 1974); although this body of literature remains extremely useful, more updated and focused studies are needed. The ability to place fossil assemblages in a robust, regional sequence stratigraphic framework is key to developing a better understanding of changes in faunal assemblages across the K-Pg boundary of southern Saskatchewan. This paper represents an important step in helping to develop this framework. By documenting the stratigraphic and geographic positions of key vertebrate microfossil localities in the RavenscragEastend-Shaunavon area, future investigators can focus their time and energy on other avenues of study and yet easily reference these significant fossil localities.

\section{Acknowledgements}


We thank R.C. Fox (UALVP) for introducing us to the fossil record of Saskatchewan and answering our numerous questions. We are indebted to the families of T. and B. Armstrong, D. Allenmand, W. Quennell, T. Pearson, and D. and R. Lundberg for their generosity in allowing us access to their lands, and to J. Hodgins for accommodations and assistance with accessing Pine Cree Regional Park. We thank the technical staff and volunteers of the RTMP for helping to collect and process microvertebrate material since 2012. We are grateful to P.A. Johnston (Mount Royal University) and P.J. Currie (UALVP) for providing access to old field photos, F. McDougall for sharing his geological knowledge of the study area, and the staff of the RSM for their assistance in obtaining collecting permits, access to paleontology collections, and for helping us develop a better understanding of the Frenchman Formation. Global Geolabs Ltd. (Calgary) prepared the palynological samples utilized in this study. C.M. Redman is grateful to J.M. Bancescu (RTMP) for her support and constructing the map figures used in this paper. This project was funded through the U.S. National Science Foundation's International Postdoctoral Fellowship program (\#OISE-1159038) awarded to C.M.R., and also benefited from staff and material support provided by the RTMP. We thank the two anonymous reviewers for their constructive comments on the submitted version of this paper. 


\section{References}

Alegret, L., Molina, E., and Thomas, E. 2001. Benthic foraminifera at the Cretaceous-Tertiary boundary around the Gulf of Mexico. Geology, 29: 891-894.

Alvarez, L.W., Alvarez, W., Asaro, F., and Michel, H.V. 1980. Extraterrestrial cause for the Cretaceous-Tertiary extinction. Science, 208: 1095-1108.

Archibald, J.D. 2014. What the dinosaur record says about extinction scenarios. In Volcanism, impacts, and mass extinctions: causes and effects. Edited by G. Keller and A.C. Kerr. Geological Society of America Special Paper, 505: 213-224.

Archibald, J.D., and Bryant, L.J. 1990. Differential Cretaceous/Tertiary extinctions of nonmarine vertebrates; Evidence from northeastern Montana. In Global Catastrophes in Earth History: An Interdisciplinary Conference on Impacts, Volcanism, and Mass Mortality. Edited by V.L. Sharpton and P.D Ward. Geological Society of America Special Paper, 247: 549-562.

Archibald, J.D., and Fastovsky, D.E. 2004. Dinosaur extinction. In The Dinosauria. Edited by D.B. Weishampel, P. Dodson, and H. Osmolska. University of California Press, Berkeley, California. Pp. 672-684.

Bamforth, E.L. 2013. Paleoecology and paleoenvironmental trends immediately prior to the EndCretaceous Extinction in the latest Maastrichtian (66 Ma) Frenchman Formation, Saskatchewan, Canada. Ph.D. dissertation, Department of Biology, McGill University, Montreal, Ontario.

Bamforth, E.L., Button, C.L., and Larsson, H.C.E. 2014. Paleoclimate estimates and fire ecology immediately prior to the end-Cretaceous mass extinction in the Frenchman Formation (66 
Ma), Saskatchewan, Canada. Palaeogeography, Palaeoclimatology, Palaeoecology, 401: 96-110.

Barrett, P., McGowan, A.J., and Page, V. 2009. Dinosaur diversity and the rock record. Proceedings of the Royal Society B, 276: 2667-2674.

Braman, D.R., and Sweet, A.R. 1999. Terrestrial palynomorph biostratigraphy of the Cypress Hills, Wood Mountain, and Turtle Mountain areas (Upper Cretaceous - Paleocene) of western Canada. Canadian Journal of Earth Sciences, 36: 725-741.

Braman, D.R., and Sweet, A.R. 2012. Biostratigraphically useful Late Cretaceous-Paleocene terrestrial palynomorphs from the Canadian Western Interior Sedimentary Basin. Palynology, 36: 8-35.

Braman, D.R., Sweet, A.R., and Lerbekmo, J.F. 1999. Upper Cretaceous-lower Tertiary lithostratigraphic relationships of three cores from Alberta, Saskatchewan, and Manitoba, Canada. Canadian Journal of Earth Sciences, 36: 669-683.

Brinkman, D.B. 1990. Paleoecology of the Judith River Formation (Campanian) of Dinosaur Provincial Park, Alberta, Canada: Evidence from vertebrate microfossil localities. Palaeogeography, Palaeoclimatology, Palaeoecology, 79: 37-54.

Brinkman, D.B., Russell, A.P., Eberth, D.A., and Peng, J. 2004. Vertebrate palaeocommunities of the lower Judith River Group (Campanian) of southeastern Alberta, Canada, as interpreted from vertebrate microfossil assemblages. Palaeogeography, Palaeoclimatology, Palaeoecology, 213: 295-313.

Brown, C.M., Boyd, C.A., and Russell, A.P. 2011. A new basal ornithopod dinosaur (Frenchman Formation, Saskatchewan, Canada) and its implications for late Maastrichtian 
ornithischian diversity in North America. Zoological Journal of the Linnean Society, 163: 1157-1198.

Buckley, G.A. 1995. The multituberculate Catopsalis from the early Paleocene of the Crazy Mountains Basin in Montana. Acta Palaeontologica Polonica, 40: 389-398.

Catuneanu O., and Sweet, A.R. 1999. Maastrichtian-Paleocene foreland-basin stratigraphies, western Canada: a reciprocal sequence architecture. Canadian Journal of Earth Sciences, 36: $685-703$.

Cifelli, R.L., Eberle, J.J., Lofgren, D.L., Lillegraven, J.A., and Clemens, W.A. 2004. Mammalian biochronology of the latest Cretaceous. In Late Cretaceous and Cenozoic mammals of North America: biostratigraphy and geochronology. Edited by M.O. Woodburne. Columbia University Press, New York. Pp. 21-42.

Clemens, W.A., Archibald, D.J., and Hickey, L.J. 1981. Out with a whimper not a bang. Paleobiology, 7: 293-298.

Currie, P.J., and Shychoski, L. 2009. "Scotty", the heaviest, and possibly oldest, Tyrannosaurus rex. In Frenchman Formation terrestrial ecosystem conference, program and extended abstracts. Edited by T.T. Tokaryk, E. Snively, and H. Bryant. Royal Saskatchewan Museum Contribution to Science, 12: 15-22.

Dawson, G.M. 1875. Report on the geology and resources in the vicinity of the Forty-ninth Parallel, from the Lake of the Woods to the Rocky Mountains. British North American Boundary Commission, Montreal, 387 pp.

Davis, N.B. 1918. Report on the clay resources of southern Saskatachewan. Mines Branch, Canadian Department of Mines, Report 468, 89 pp. 
Demar, D.G., Jr., and Breithaupt, B.H. 2006. The nonmammalian vertebrate microfossil assemblages of the Mesaverde Formation (Upper Cretaceous, Campanian) of the Wind River and Bighorn Basins, Wyoming. Bulletin of the New Mexico Museum of Natural History and Science, 35: 33-53.

Eberth, D.A. 1990. Stratigraphy and sedimentology of vertebrate microfossil sites in the uppermost Judith River Formation (Campanian), Dinosaur Provincial Park, Alberta, Canada. Palaeogeography, Palaeoclimatology, Palaeoecology, 78: 1-36.

Eberth, D.A., Shannon, M., and Noland, B.G. 2007. A bonebeds database: classification, biases and patterns of occurrence. In Bonebeds: Genesis, Analysis, and Paleobiological Significance. Edited by R.R. Rogers, D.A. Eberth, and A.R. Fiorillo. University of Chicago Press, Chicago, Pp. 103-219.

Fox, R.C. 1989, The Wounded Knee Local Fauna and Mammalian Evolution near the Cretaceous-Tertiary boundary, Saskatchewan, Canada. Palaeontographica Abt. A, 208: $11-59$.

Fox, R.C. 1990. Succession of Paleocene mammals in western Canada. In Dawn of the Age of Mammals in the northern part of the Rocky Mountain Interior, North America. Edited by T.M. Bown and K.D. Rose. Geological Society of America Special Paper, 243: 51-70.

Fox, R.C. 2002. The oldest Cenozoic mammal? Journal of Vertebrate Paleontology, 22: 456459.

Fox, R.C. 2005. Microcosmodontid multituberculates (Allotheria, Mammalia) from the Paleocene and Late Cretaceous of western Canada. Palaeontographica Canadiana, 23: 1109. 
Fox, R.C., and Scott, C.S. 2011. A new, early Puercan (earliest Paleocene) species of Purgatorius (Plesiadapiformes, Primates) from Saskatchewan, Canada. Journal of Paleontology, 85: 537-548.

Fox, R.C., and Youzwyshyn, G.P. 1994. New primitive carnivorans (Mammalia) from the Paleocene of western Canada, and their bearing on relationships of the order. Journal of Vertebrate Paleontology, 14: 382-404.

Fox, R.C., Scott, C.S., and Bryant, H.N. 2007. A new, unusual therian mammal from the Upper Cretaceous of Saskatchewan, Canada. Cretaceous Research, 28: 821-829.

Fox, R.C., Scott, C.S., and Rankin, B.D. 2010. New early carnivoran specimens from the Puercan (earliest Paleocene) of Saskatchewan, Canada. Journal of Paleontology, 84: $1035-1039$.

Fraser, F.J., McLearn, F.H., Russell, L.S., Warren, P.S., and Wickenden, R.T.D. 1935. Geology of southern Saskatchewan. Canada Geological Survey Memoir, 176: 1-137.

Furnival, G.M. 1946. Cypress Lake map-area Saskatchewan. Geological Survey of Canada Memoir, 242: 1-161.

Gao, K., and Fox, R.C. 1996. Taxonomy and evolution of Late Cretaceous lizards (Reptilia: Squamata) from western Canada. Bulletin of Carnegie Museum of Natural History, 33: 1-107.

Gardner, J.M., and DeMar, D.G., Jr. 2013. Mesozoic and Palaeocene lissamphibian assemblages of North America: a comprehensive review. Palaeobiodiversity and Palaeoenvironments, 93: 459-515.

Hartman, J.H., G.A. Buckley, D.W. Krause, and T.J. Kroeger. 1989. Paleontology, stratigraphy, and sedimentology of Simpson Quarry (early Paleocene), Crazy Mountains Basin, South- 
central Montana. Montana Geological Society Guidebook, Geologic Resources of Montana 1: 173-185.

Hartman, J.H., Johnson, K.R., and Nichols, D.J. (eds.) 2002. The Hell Creek Formation and the Cretaceous-Tertiary boundary in the Northern Great Plains: an Integrated Continental Record of the End of the Cretaceous. Geological Society of America Special Paper, 361.

Hendry, H.E. 1990. Frenchman Formation. In Lexicon of Canadian Stratigraphy Volume 4:

Western Canada, including Eastern British Columbia, Alberta, Saskatchewan, and Southern Manitoba. Edited by D.J. Glass. Canadian Society of Petroleum Geologists, Calgary, Alberta. Pp. 245-246.

Hicks, J.F., Obradovich, J.D., and Tauxe, T. 1999. Magnetostratigraphy, isotopic age correlation and intercontinental correlation of the Red Bird section of the Pierre Shale, Niobrara County, Wyoming, USA. Cretaceous Research, 20: 1-27.

Hicks, J.F., Johnson, K.R., Obradovich, J.D., Tauxe, L., and Clark, D. 2002. Magnetostratigraphy and geochronology of the Hell Creek and basal Fort Union Formations of southwestern North Dakota and a recalibration of the age of the Cretaceous-Tertiary boundary. In The Hell Creek Formation and the Cretaceous-Tertiary Boundary in the Northern Great Plains: an integrated continental record of the end of the Cretaceous. Edited by J.H. Hartman, K.R. Johnson, and D.J., Nichols. Geological Society of America Special Paper, 361: 35-55.

Hulbert, S.H., and Archibald, J.D. 1995. No statistical support for sudden (or gradual) extinction of dinosaurs. Geology, 23: 881-884.

Jamniczky, H.A., Brinkman, D.B., and Russell, A.P. 2003. Vertebrate microsite sampling: How much is enough? Journal of Vertebrate Paleontology, 23: 725-734. 
Johnston, P.A. 1980a. First record of Mesozoic mammals from Saskatchewan. Canadian Journal of Earth Sciences, 17: 512-519.

Johnston, P.A. 1980b. Late Cretaceous and Paleocene mammals from southwestern Saskatchewan. M.Sc. thesis, Department of Geology, The University of Alberta, Edmonton, Alberta.

Johnston, P.A., and Fox, R.C. 1984. Paleocene and Late Cretaceous mammals for Saskatchewan, Canada. Palaeontographica Abt. A, 186: 163-222.

Keller, G. 1989. Extended period of extinctions across the Cretaceous/Tertiary boundary in planktonic foraminifera of continental-shelf sections: Implications for impact and volcanism theories. Geological Society of American Bulletin, 101: 1408-1419.

Kielan-Jaworowska, Z., Cifelli, R.L., and Luo, Z-X. 2004. Mammals from the Age of Dinosaurs: Origins, Evolution, and Structure. Columbia University Press, New York.

Krause, D.W. 1977. Paleocene multituberculates (Mammalia) of the Roche Percèe local fauna, Ravenscrag Formation, Saskatchewan, Canada. Palaeontographica Abt. A, 159: 1-36. Kupsch, W.O. 1956. Frenchman Formation of eastern Cypress Hills, Saskatchewan, Canada. Geological Society of America Bulletin, 68: 413-420.

LeCain, R., Clyde, W.C., Wilson, G.P., and Riedel, J. 2014. Magnetostratigraphy of the Hell Creek and lower Fort Union Formations in northeastern Montana. In Through the end of the Cretaceous in the type locality of the Hell Creek Formation in Montana and adjacent areas. Edited by G.P. Wilson, W.A. Clemens, J.R. Horner, and J.H. Hartman. Geological Society of America Special Paper, 503: 137-147. 
Lerbekmo, J.F. 1985. Magnetostratigraphic and biostratigraphic correlations of Maastrichtian to early Paleocene strata between south-central Alberta and southwestern Saskatchewan. Bulletin of Canadian Petroleum Geology, 33: 213-226.

Lerbekmo, J.F. 1987. Magnetostratigraphic restrictions on the age of the Frenchman Formation and the magnitude of the sub-Frenchman disconformity in southwest Saskatchewan. Bulletin of Canadian Petroleum Geology, 35: 454-459.

Lerbekmo, J.F. 2009. Glacioeustatic sea level fall marking the base of supercycle TA-1 at 66.5 Ma recorded by the kaolinization of the Whitemud Formation and the Colgate Member of the Fox Hills Formation. Marine and Petroleum Geology, 26: 1299-1303.

Lerbekmo, J.F., and Braman, D.R. 2002. Magnetostratigraphic and biostratigraphic correlation of late Campanian and Maastrichtian marine and continental strata from the Red Deer Valley to the Cypress Hills, Alberta Canada. Canadian Journal of Earth Sciences, 39: 539-557.

Lerbekmo, J.F., and Sweet, A.R. 2000. Magnetostratigraphy and biostratigraphy of the continental Paleocene in the Calgary area, southwestern Alberta. Bulletin of Canadian Petroleum Geology, 48: 285-306.

Lerbekmo, J.F., Sweet, A.R., and St. Louis, R.M. 1987. The relationship between the iridium anomaly and palynological flora events at three Cretaceous-Tertiary boundary localities in western Canada. Geological Society of American Bulletin, 99: 325-330.

Lerbekmo, J.F., Sweet, A.R., and Duke, M.J.M. 1996. A normal polarity subchron that embraces the K/T boundary: A measure of sedimentary continuity across the boundary and synchoneity of boundary events. In The Cretaceous-Tertiary event and other catastrophes 
in Earth history. Edited by G. Ryder, D. Fastovsky, and S. Gartner. Geological Society of America Special Papers, 307: 465-476.

Lillegraven, J.A. 1969. Latest Cretaceous mammals of upper part of Edmonton Formation of Alberta, Canada, and review of marsupial-placental dichotomy in mammalian evolution. The University of Kansas Paleontological Contributions Article, 50 (Vertebrata 12): 1122.

Lillegraven, J.A., and Eberle, J.J. 1999. Vertebrate faunal changes through Lancian and Puercan time in southern Wyoming. Journal of Paleontology, 73: 691-710.

Lloyd, G.T., Davis, K.E., Pisani, D., Tarver, J.E., Ruta, M., Sakamoto, M., Hone, D., Jennings, R., and Benton, M.J. 2008. Dinosaurs and the Cretaceous terrestrial revolution. Proceedings of the Royal Society B, 275: 2483-2490.

Lofgren, D.L., Lillegraven, J.A., Clemens, W.A., Gingerich, P.D., and Williamson, T.E. 2004. Paleocene biochronology: the Puercan through Clarkforkian Land Mammal Ages. In Late Cretaceous and Cenozoic mammals of North America: biostratigraphy and geochronology. Edited by M.O. Woodburne. Columbia University Press, New York. Pp. 43-105.

Lofgren, D.L., Scherer, B.E., Clark, C.K., and Standhardt, B. 2005. First record of Stygimys (Mammalia, Multituberculata, Eucosmodontidae) from the Paleocene (Puercan) part of the North Horn Formation, Utah, and a review of the genus. Journal of Mammalian Evolution, 12: 77-97.

Lucas, S.G., Williamson, T.E., and Middleton, M.D. 1997. Catopsalis (Mammalia: Multituberculata) from the Paleocene of New Mexico and Utah: taxonomy and biochronological significance. Journal of Paleontology, 71: 484-493. 
Markwick, P.J. 1998. Crocodilian diversity in space and time: the role of climate in paleoecology and its implication for understanding K/T extinctions. Paleobiology, 24: $470-497$.

McKenzie-McAnally, L. (ed.) 1997. Upper Cretaceous and Tertiary stratigraphy and paleontology of southern Saskatchewan. Canadian Paleontology Conference Field Trip Guidebook No. 6, Geological Association of Canada, St. John's, Newfoundland. Pp. 1155.

McIver, E.E. 1989. Fossil flora of the Paleocene Ravenscrag Formation, southwestern Saskatchewan, Canada. Ph.D. dissertation, Department of Biology, The University of Saskatchewan, Saskatoon, Saskatchewan.

McIver, E.E. 2002. The paleoenvironment of Tyrannosaurus rex from southwestern Saskatchewan, Canada. Canadian Journal of Earth Sciences, 39: 207-221.

McIver, E.E., and Basinger, J.F. 1993. Flora of the Ravenscrag Formation (Paleocene), southwestern Saskatchewan, Canada. Palaeontographica Canadiana, 10: 1-167.

McLearn, F.H. 1929. Southern Saskatchewan. Canada Geological Survey Summary Report 1928, Part B: 30-45.

Nichols, D.J., and Johnson, K.R. 2008. Plants and the K-T boundary. Cambridge University Press, Cambridge, United Kingdom.

Nichols, D.J., and Ott, H.L. 1978. Biostratigraphy and evolution of the MomipitesCaryapollenites lineage in the Early Tertiary in the Wind River Basin, Wyoming. Palynology, 2: 93-112.

Paulina Carabajal, A., and Currie, P.J. 2009. Comparison of the braincases of a Tyrannosaurus rex ("Scotty") with other tyrannosaurids. In Frenchman Formation terrestrial ecosystem 
conference, program and extended abstracts. Edited by T.T. Tokaryk, E. Snively, and H. Bryant. Royal Saskatchewan Museum Contribution to Science, 12: 32-39.

Renne, P.R., Deino, A.L., Hilgen, F.J., Kuiper, K.F., Mark, D.F., Mitchell, W.S., III, Morgan, L.E., Mundil, R., and Smit, J. 2013. Time scales of critical events around the CretaceousPaleogene boundary. Science, 339: 684-687.

Rogers, R.R., and Brady, M.E., 2010. Origins of microfossil bonebeds: insights from the Upper Cretcaeous Judith River Formation of north-central Montana. Paleobiology, 36: 80-112.

Russell, D.A. 1984. The gradual decline of the dinosaurs-fact of fallacy? Nature, 307: 360-361.

Russell, L.S. 1948. The geology of the southern part of the Cypress Hills, southwestern Saskatchewan. Department of Mineral Resources Geological Sciences Branch Preliminary Report No. 8, 60 pp.

Russell, L.S. 1974. Fauna and correlation on the Ravenscrag Formation (Paleocene) of southwestern Saskatchewan. Royal Ontario Museum Life Sciences Contribution, 102: 152.

Russell, L.S. 1975. Mammalian faunal succession in the Cretaceous System of western North America. In The Cretaceous System in the Western Interior of North America. Edited by W.G.E. Caldwell. Geological Association of Canada Special Paper, 13: 137-161.

Sankey, J.T., and Baszio, S. (eds.) 2008. Vertebrate Microfossil Assemblages Their Role in Paleoecology and Paleobiogeography. Indiana University Press, Bloomington.

Sepkoski, J.J. 1996. Patterns of Phanerozoic extinction: a perspective for global data bases. In Global events and event stratigraphy. Edited by O.H. Walliser. Springer Press, Berlin, Germany. Pp. 31-51.

Sessa, J.A., Bralower, T.J., Patzkowsky, M.E., Handley, J.C., and Ivany, L.C. 2012. 
Environmental and biological controls on the diversity and ecology of Late Cretaceous through early Paleogene marine ecosystems in the U.S. Gulf Coastal Plain. Paleobiology, 38: $218-239$.

Sheehan, P.M., and Fastovsky, D.E. 1992. Major extinctions of land-dwelling vertebrates at the Cretaceous-Tertiary boundary, eastern Montana. Geology, 20: 556-560.

Sheehan, P.M., Fastovsky, D.E., Barreto, C., and Hoffman, R.G. 2000. Dinosaur abundance was not declining in a "3 m gap" at the top of the Hell Creek Formation, Montana and North Dakota. Geology, 28: 523-526.

Sloan, R.E., Rigby, J.K., Van Valen, L.M., and Gabriel, D. 1986. Gradual dinosaur extinction and simultaneous ungulate radiation in the Hell Creek Formation. Science, 232: 629-633.

Spivak, D.N. 1997. Early Paleogene (Puercan) mammals from the Ravenscrag Formation, Saskatchewan, Canada. $57^{\text {th }}$ Annual Meeting of Society of Vertebrate Paleontology, Chicago, Illinois, Oct. 8-1 $1^{\text {th }}$, 1997, Journal of Vertebrate Paleontology, 17 (supplement to 3$): 78 \mathrm{~A}$

Srivastava, S.K. 1966. Upper Cretaceous microflora (Maestrichtian) from Scollard, Alberta, Canada. Pollen et Spores, 8: 497-552.

Srivastava, S.K. 1968. Eight species of Mancicorpus from the Edmonton Formation (Maestrichtian), Alberta, Canada. Canadian Journal of Botany, 46: 1485-1490.

Srivastava, S.K. 1970. Pollen biostratigraphy and paleoecology of the Edmonton Formation (Maestrichtian), Alberta, Canada. Palaeogeography, Palaeoclimatology, Palaeoecology, 7: $221-276$.

Storer, J.E. 1991. The mammals of the Gryde local fauna, Frenchman Formation (Maastrichtian: Lancian), Saskatchewan. Journal of Vertebrate Paleontology, 11: 350-369. 
Storer, J.E. 1993. Additions to the mammalian palaeofauna of Saskatchewan. Modern Geology, 18: 475-487.

Sweet, A.R. 1994. Relationships between depositional environments and changes in palynofloras across the K/T boundary interval. In Sedimentation of Organic Particles. Edited by A. Traverse. Cambridge University Press, Cambridge, UK. Pp. 461-488.

Sweet, A.R., and Braman, D.R. 1992. The K-T boundary and contiguous strata in western Canada: interactions between paleoenvironments and palynological assemblages. Cretaceous Research, 13: 31-79.

Sweet, A.R., Braman, D.R., and Lerbekmo, J.F. 1999. Sequential palynological changes across the composite Cretaceous-Tertiary (K-T) boundary claystone and contiguous strata, western Canada and Montana, U.S.A. Canadian Journal of Earth Sciences, 36: 743-768.

Therrien, F., Eberth, D.A., Braman, D.R., and Zelenitsky, D.K. 2007. High-resolution organic carbon isotope record across the Cretaceous-Tertiary boundary in south-central Alberta: Implications for the post-impact recovery rate of terrestrial ecosystems and use of $\delta 13 \mathrm{C}$ as a boundary marker. Canadian Journal of Earth Sciences, 44: 529-542.

Tokaryk, T.T. 1986. Ceratopsian dinosaurs from the Frenchman Formation (Upper Cretaceous) of Saskatchewan. The Canadian Field-Naturalist, 100: 192-196.

Tokaryk, T.T. 1997. First evidence of juvenile ceratopsians (Reptilia: Ornithischia) from the Frenchman Formation (late Maastrichtian) of Saskatchewan. Canadian Journal of Earth Sciences, 34: 1401-1404.

Tokaryk, T.T., and Bryant, H.N. 2004. The fauna from the Tyrannosaurus rex excavation, Frenchman Formation (Late Maastrichtian), Saskatchewan [online]. Summary of 
Investigations Volume 1, Saskatchewan Geological Survey, Saskatchewan Industry Resources, Miscellaneous Report 2004-4.1, Paper A-I8: 1-12.

Tokaryk, T.T., and James, P.C. 1989. Cimolopteryx sp. (Aves, Charadriiformes) from the Frenchman Formation (Maastrichtian), Saskatchewan. Canadian Journal of Earth Sciences, 26: 2729-2730.

Tokaryk, T.T., Snively, E., and Bryant, H. 2009. Frenchman Formation terrestrial ecosystem conference, program and extended abstracts. Royal Saskatchewan Museum Contribution to Science, 12: 1-73.

Wang, S.C., and Dodson, P. 2006. Estimating the diversity of dinosaurs. PNAS, 103: 1360113605.

Wilf, P., Labandeira, C.C, Johnston, K.R., and Ellis, B. 2006. Decoupled plant and insect diversity after the end-Cretaceous extinction. Science, 313: 1112-1115.

Williams, M.Y., and Dyer, W.S. 1930. Geology of southern Alberta and southwestern Saskatchewan. Canada Geological Survey Memoir, 163:1-160.

Wilson, G.P., Clemens, W.A., Horner, J.R., and Hartman, J.H. (eds.) 2014. Through the end of the Cretaceous in the type locality of the Hell Creek Formation in Montana and adjacent areas. Geological Society of America Special Paper, 503.

Woodburne, M.O. 2004. Principles and Procedures. In Late Cretaceous and Cenozoic mammals of North America: biostratigraphy and geochronology. Edited by M.O. Woodburne. Columbia University Press, New York. Pp. 1-20. 


\section{Figure Captions}

Fig. 1. Map of the Ravenscrag-Eastend-Shaunavon area in southwestern Saskatchewan, Canada, showing the study area and locations of the 11 microsites documented in this study. Insert map depicts western Canada, with the Province of Saskatchewan shaded and the study area indicated. Microsites are numbered west-to-east as follows: Croc Pot (1); Rav W-1 and Long Fall (2); Fr-1 (3); Pine Cree (4); By Gar Gap (5); Hairpin (6); French Fry (7); Wounded Knee (8); Wounded C (9); and Gryde (10). Topographic maps of key areas are labeled A, B, C and correspond to same areas depicted at larger scale in Figures 3, 7, and 9, respectively.

Fig. 2. Lithostratigraphic correlations of uppermost Cretaceous and lower Paleocene formations in central Alberta, southwestern Saskatchewan, eastern Montana (MT), and western North Dakota (ND). Magnetostratigraphy is based on: Hicks et al. 1999; Catuneanu and Sweet 1999; Lerbekmo and Sweet 2000; Hicks et al. 2002; Lerbekmo and Braman 2002; Lerbekmo 2009; and LeCain et al. 2014.

Fig. 3. Topographic map for the area west of Ravenscrag, Saskatchewan (Fig. 1A), showing locations of the following four microsites: Croc Pot (1); Rav W-1 and Long Fall (2); and Fr-1 (3). Legal land descriptions for these microsites are: SE1/4, S21, T6, R24, W3 (Croc Pot); NW1/4, S23, T6, R24, W3 (Rav W-1 and Long Fall); and SE1/4, S26, T6, R24, W3 (Fr-1).

Fig. 4. Key to the lithological symbols used in the measured sections (see Figs. 5, 6, 8, and 1013). 
Fig. 5. Measured section at the Croc Pot microsite (1), in the Ravenscrag Formation. The Ravenscrag Formation unconformably overlies the Eastend Formation and is unconformably capped by a conglomerate of the Eocene-Miocene age Cypress Hills Formation. The Ferris Coal Seam is not exposed in the area, meaning the position of Croc Pot within the Ravenscrag Formation is uncertain. Small arrows denote positions where six palynomorph samples were taken. For locality photograph, see online supplemental Fig. 1A. Solid lines mark formational contacts. Vertical axis is in meters.

Fig. 6. Measured section at the Fr-1 microsite (3) in the Frenchman Formation. The Frenchman Formation cuts down into the Battle Formation, which rests conformably on the Whitemud Formation. The Ferris Coal Seam is not exposed in the area, meaning the position of the upper boundary of the Frenchman Formation is not known. Small arrows denote positions where five palynomorph samples were taken. For locality photograph, see online supplemental Fig. 3. Solid lines mark formational contacts; question mark (?) indicates uncertain placement of boundary between Frenchman and Ravenscrag formations (see text). Vertical axis is in meters.

Fig. 7. Topographic map for the area around Pine Cree Regional Park (Fig. 1B), showing locations of the Pine Cree (4) and By Gar Gap (5) microsites near Highway 633, northeast of Eastend, Saskatchewan. Legal land descriptions for these microsites are: SW1/4, S02, T8, R21, W3 (Pine Cree) and NW1/4, S36, T7, R21, W3 (By Gar Gap). 
Fig. 8. Measured, composite section along Highway 633 and at the Pine Cree microsite.

Placement of the Pine Cree section (indicated by dashed borders) is based on the elevation of the microsite relative to the Ferris Coal Seam, where the latter is exposed farther to the east along Highway 633. The Pine Cree microsite (4) is in the Ravenscrag Formation, whereas the By Gar Gap microsite (5) is in the Frenchman Formation. Small arrows denote positions where five palynomorph samples were taken in the Pine Cree section. For locality photographs, see online supplemental Figs. 4 and 5 (Pine Cree and By Gar Gap, respectively). Solid lines mark formational contacts. Vertical axis is in meters.

Fig. 9. Topographic map for the area where Highway 37 crosses the Frenchman River Valley, south of Shaunavon, Saskatchewan (Fig. 1C), showing locations of the following five microsites: Hairpin (6); French Fry (7); Wounded Knee (8); Wounded C (9); and Gryde (10). Dashed line represents a major power line. Legal land descriptions for these microsites are: SE $1 / 4 \mathrm{~S} 16$, T5, R19, W3 (Hairpin); NE1/4 S31, T4, R18, W3 (French Fry, Wounded Knee, and Wounded C); and NW1/4, S19, T4, R18, W3 (Gryde).

Fig. 10. Measured section at the Hairpin microsite (6) in the Frenchman Formation. Asterisk $\left(^{*}\right)$ marks the approximate stratigraphic position of the RSM Tyrannosaurus rex "Scotty" quarry located northwards into Chambery Coulee. For Hairpin locality photograph, see online supplemental Fig. 6. Solid lines mark formational contacts. Vertical axis is in meters.

Fig. 11. Measured section along the east side of Highway 37. French Fry (7) is in the Ravenscrag Formation, whereas Wounded C (9) and Wounded Knee (8) are both in the Frenchman 
Formation. The exact stratigraphic position of Wounded Knee is uncertain (see text for discussion), but based on our measurements lies 10-15 m below the Ferris Coal Seam. For locality photographs, see online supplemental Figs 7-9. Solid lines mark formational contacts. Vertical axis is in meters.

Fig. 12. Measured section at the Gryde microsite (10) in the Frenchman Formation. The Ferris Coal Seam is not exposed in the immediate area, meaning the position of Gryde within the Frenchman Formation is uncertain. For locality photograph, see online supplemental Fig. 10. Vertical axis is in meters.

Fig 13. Regional correlation from west-to-east across the Ravenscrag-Eastend-Shaunavon area of simplified stratigraphic sections presented in this study (see Figs.5, 6, 8, and 10-12). Dashed lines show correlations of major lithostratigraphic units containing nine microsites (Croc Pot (1); Fr-1 (3); Pine Cree (4); By Gar Gap (5); Hairpin (6); French Fry (7); Wounded Knee (8); Wounded C (9); Gryde (10)) within the Frenchman and Ravenscrag formations. Positions of the other two microsites (Rav W-1 and Long Fall (3)), both within the Medicine Hat Brick and Tile Quarry are not shown, because neither microsite is accessible due to the quarry having been filled in and reclaimed in 2011 (see text). Solid lines mark formational contacts; question mark (?) indicates uncertain placement of boundary between Frenchman and Ravenscrag formations for the Fr-1 section (see text). Vertical axis is in meters. 


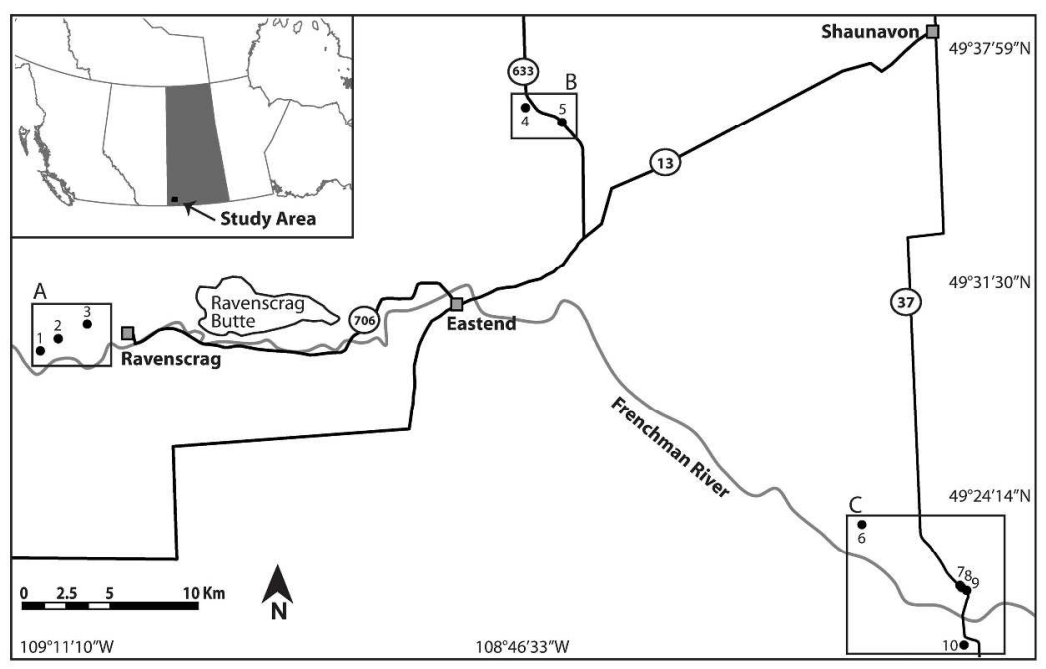

$279 \times 361 \mathrm{~mm}(300 \times 300$ DPI $)$ 


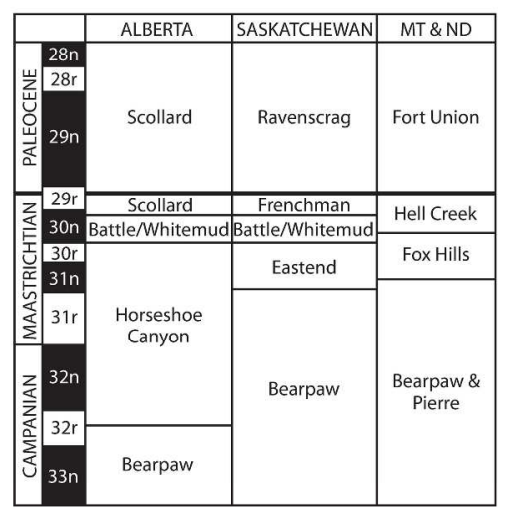

$279 \times 361 \mathrm{~mm}(300 \times 300 \mathrm{DPI})$ 


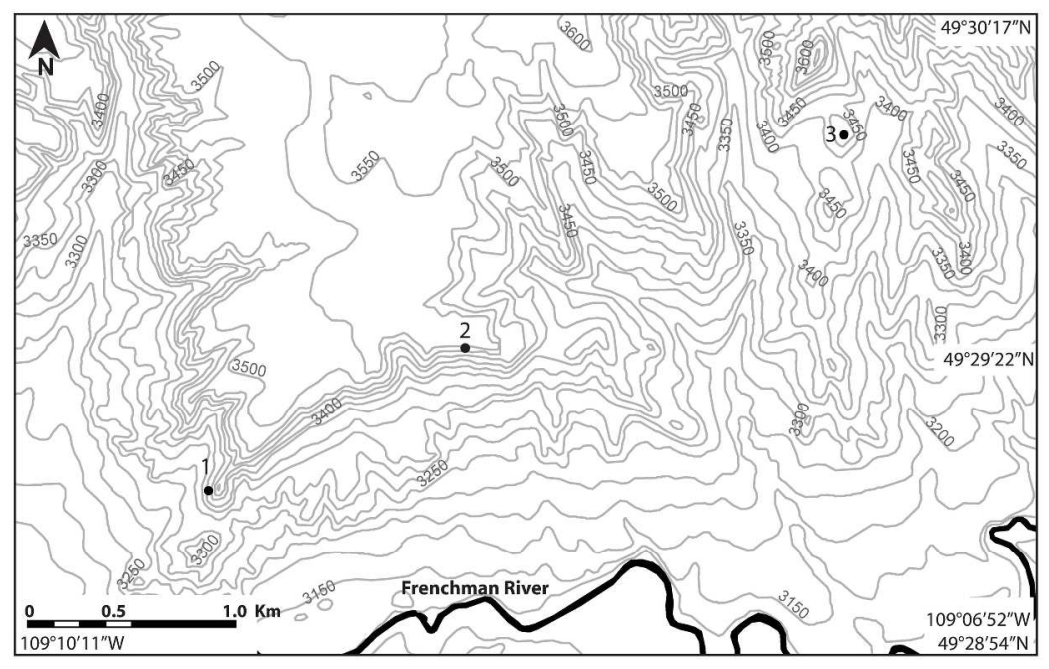

$279 \times 361 \mathrm{~mm}(300 \times 300 \mathrm{DPI})$ 


\begin{tabular}{|c|c|c|}
\hline$\bowtie$ & Covered & $\begin{array}{l}\text { Unconformity } \\
\text { \&ud Clasts }\end{array}$ \\
\hline & Laminated & Concretions \\
\hline 6 & Conglomerate & $\begin{array}{cl}0000 \text { \& } & \text { Burrows } \\
\boldsymbol{\lambda} & \text { Roots }\end{array}$ \\
\hline & Lignite & $\approx$ Organics \\
\hline & Claystone & $\cong$ Wood \\
\hline E.:- & Siltstone & Invertebrates \\
\hline & Massive Sandstone & \multirow{3}{*}{ 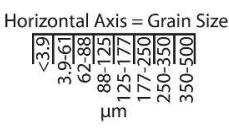 } \\
\hline & Rippled Sandstone & \\
\hline & $\mathrm{X}$-bedded Sandstone & \\
\hline
\end{tabular}

$279 \times 361 \mathrm{~mm}(300 \times 300 \mathrm{DPI})$

https://mc06.manuscriptcentral.com/cjes-pubs 


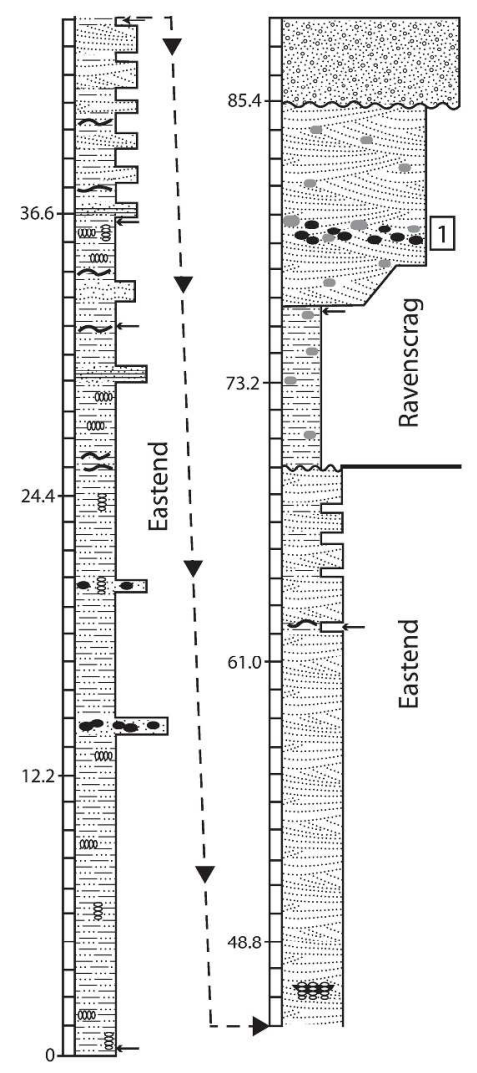

$279 \times 361 \mathrm{~mm}(300 \times 300$ DPI $)$

https://mc06.manuscriptcentral.com/cjes-pubs 


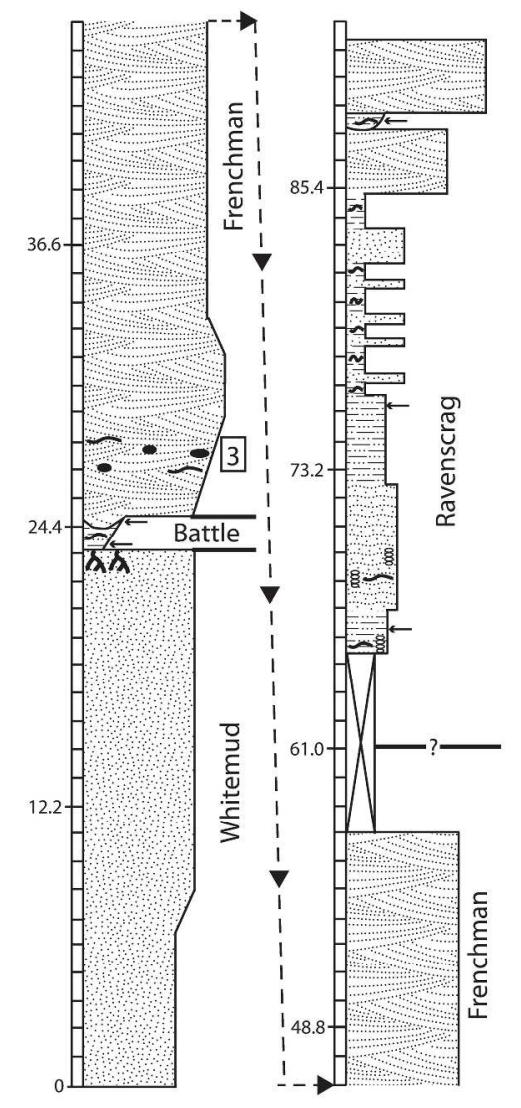

$279 \times 361 \mathrm{~mm}(300 \times 300 \mathrm{DPI})$

https://mc06.manuscriptcentral.com/cjes-pubs 


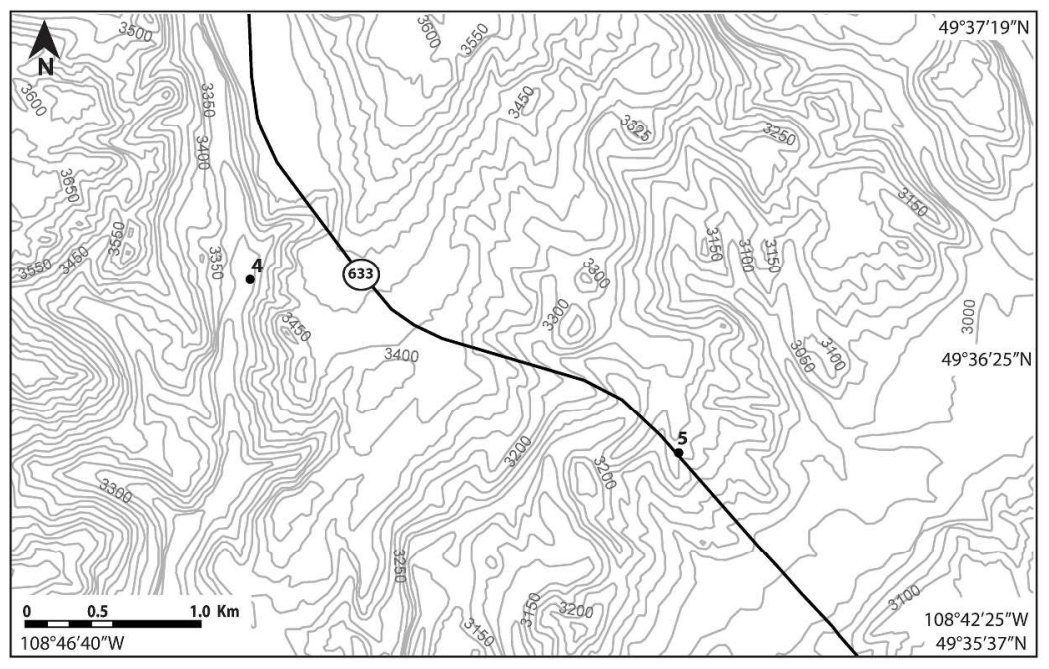

$279 \times 361 \mathrm{~mm}(300 \times 300 \mathrm{DPI})$

https://mc06.manuscriptcentral.com/cjes-pubs 


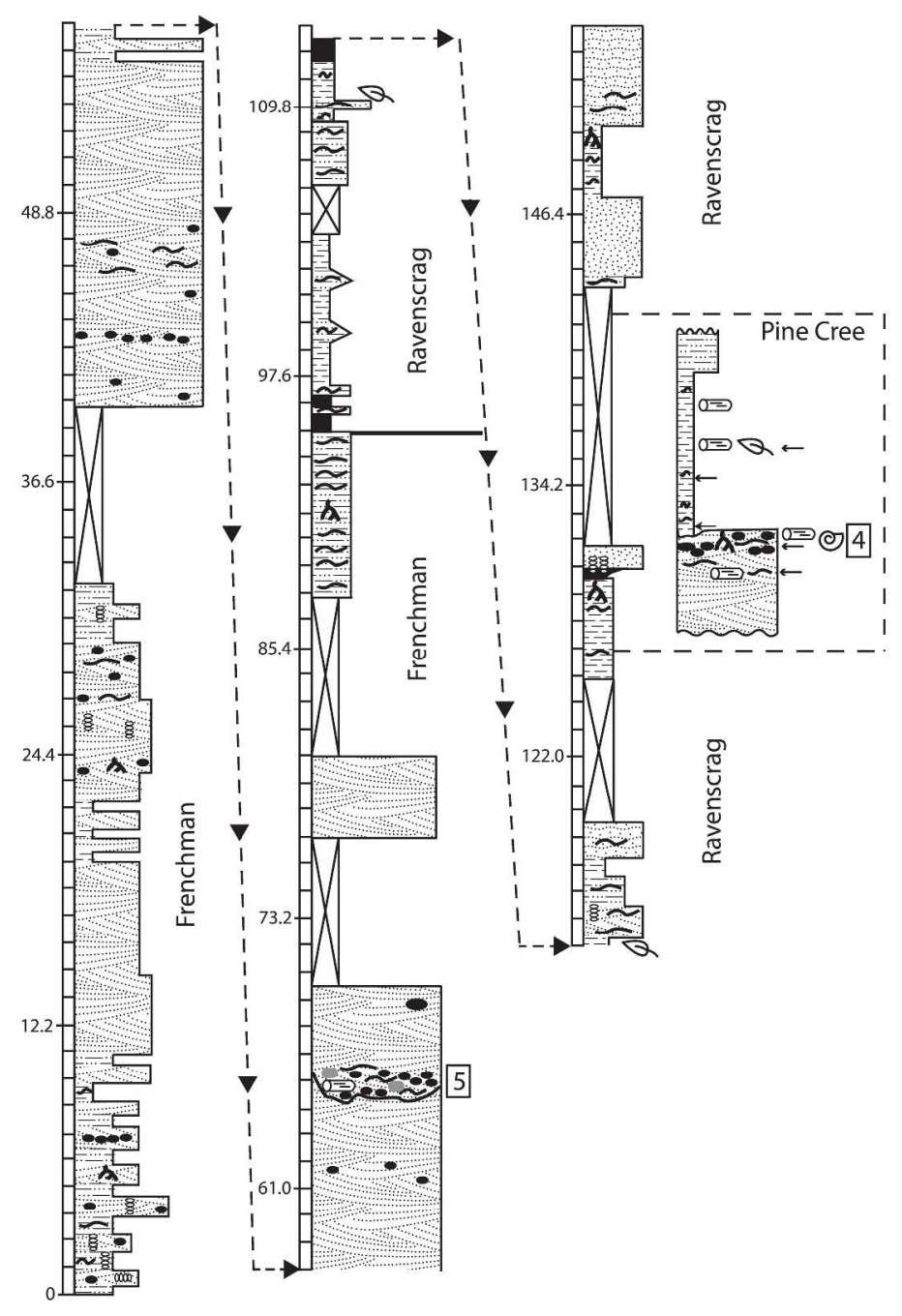

$279 \times 361 \mathrm{~mm}(300 \times 300$ DPI $)$ 


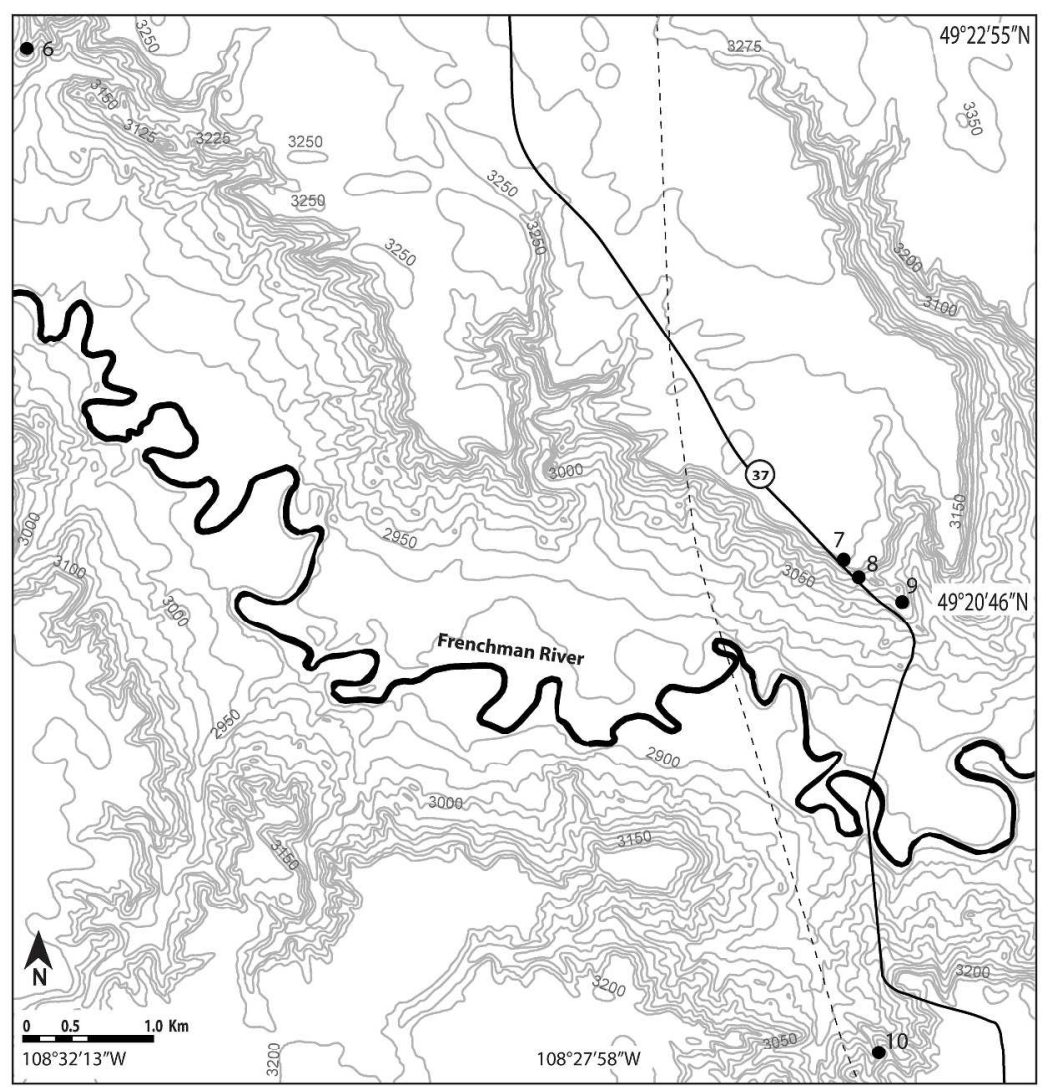

$279 \times 361 \mathrm{~mm}(300 \times 300 \mathrm{DPI})$ 


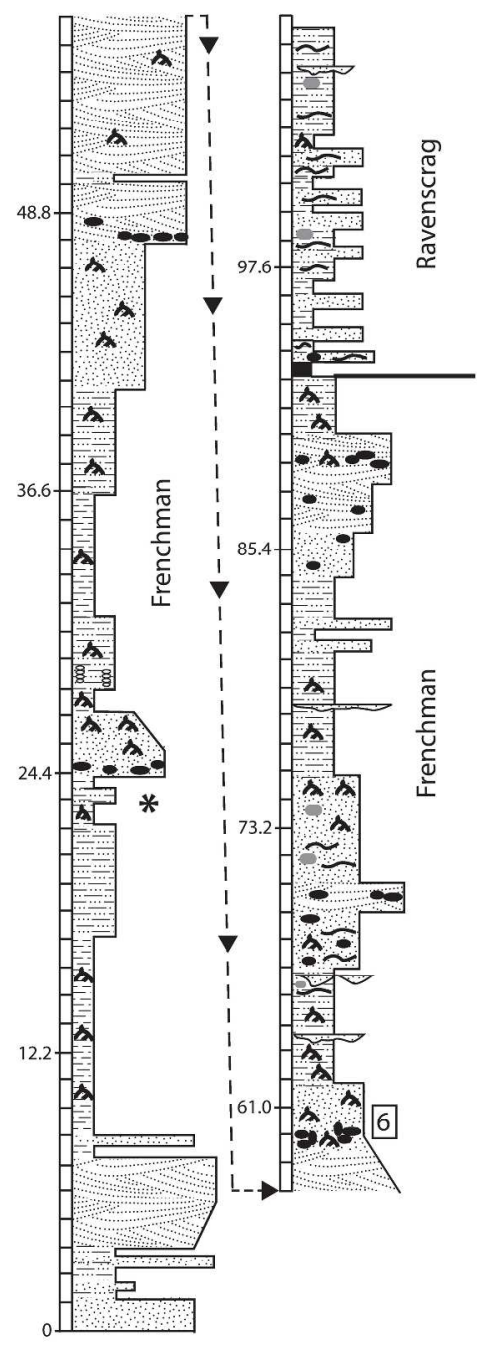

$279 \times 361 \mathrm{~mm}(300 \times 300$ DPI $)$ 


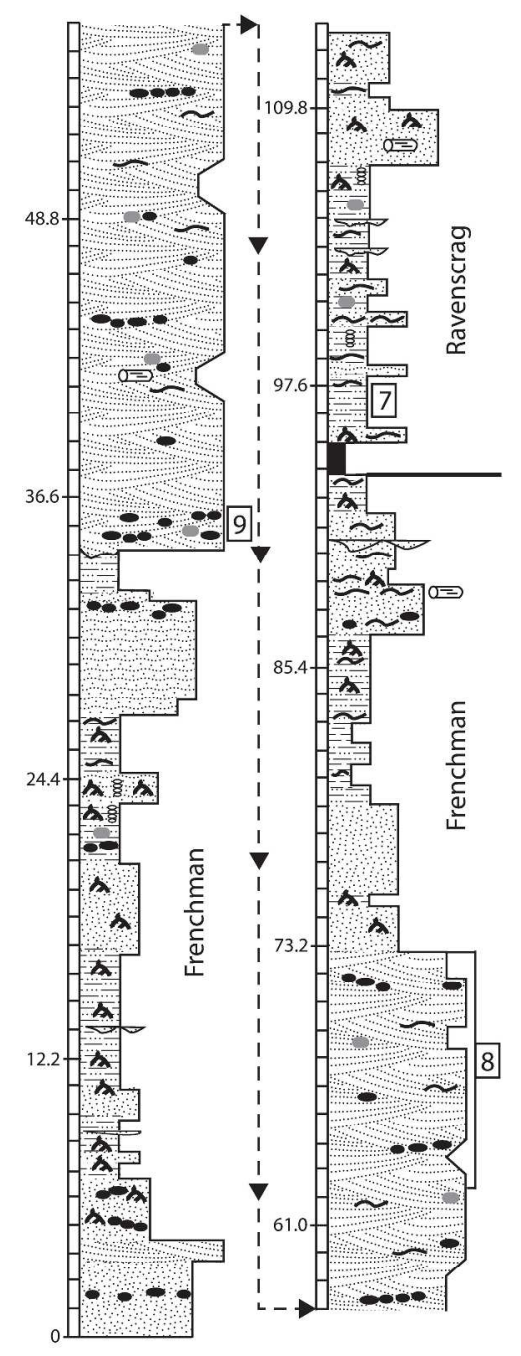

$279 \times 361 \mathrm{~mm}(300 \times 300 \mathrm{DPI})$ 


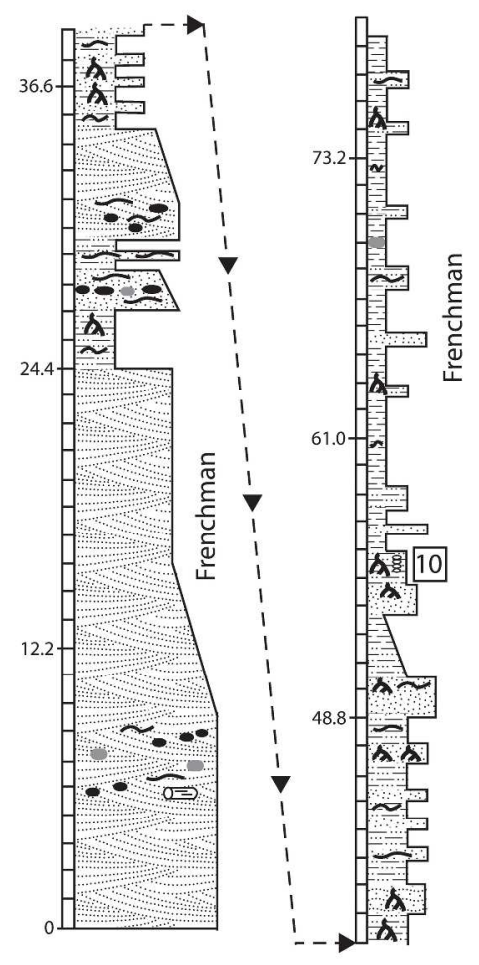

$279 \times 361 \mathrm{~mm}(300 \times 300$ DPI $)$ 


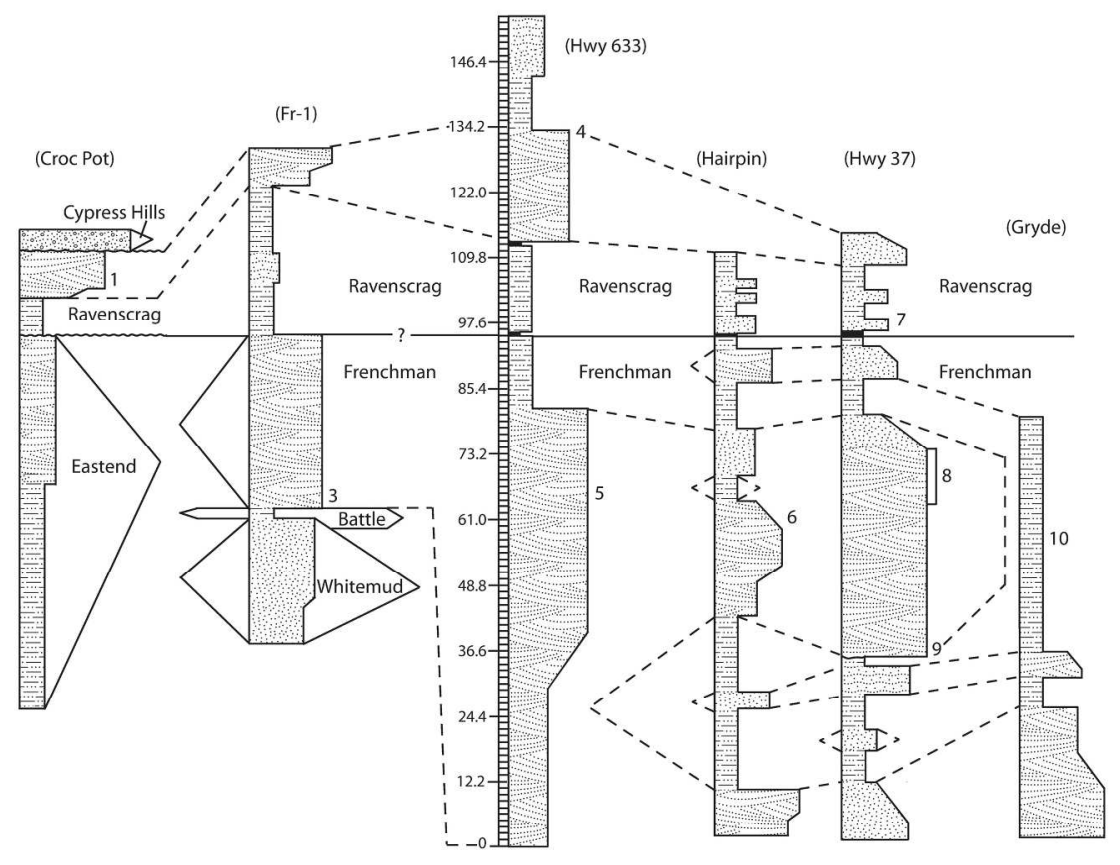

$215 \times 166 \mathrm{~mm}(300 \times 300 \mathrm{DPI})$ 